\title{
Which Meteorological and Climatological Information Is Requested for Better Surfing Experiences? A Survey-Based Analysis
}

\author{
Anna Boqué Ciurana *(D) and Enric Aguilar (D) \\ Centre for Climate Change, C3, Geography Department, Universitat Rovira i Virgili, 43480 Vila-seca, Spain; \\ enric.aguilar@urv.cat \\ * Correspondence: anna.boque@urv.cat
}

check for updates

Citation: Boqué Ciurana, A.; Aguilar, E. Which Meteorological and Climatological Information Is Requested for Better Surfing Experiences? A Survey-Based Analysis. Atmosphere 2021, 12, 293. https://doi.org/10.3390/ atmos12030293

Academic Editor: M. Belén Gómez Martín

Received: 8 February 2021

Accepted: 20 February 2021

Published: 24 February 2021

Publisher's Note: MDPI stays neutral with regard to jurisdictional claims in published maps and institutional affiliations.

Copyright: (c) 2021 by the authors. Licensee MDPI, Basel, Switzerland. This article is an open access article distributed under the terms and conditions of the Creative Commons Attribution (CC BY) license (https:/ / creativecommons.org/licenses/by/ $4.0 /)$.

\begin{abstract}
This paper extends the work of previous research by investigating surfing practices and surf-recreation companies from a behavioral perspective. The study's main aim is to gain insights into the role of meteorological/climatological information in decision-making related to the surf-tourism activities market. This information was gathered employing an online survey that asked respondents about where they surf and how they check forecasts for surfing. Climate services (CS) are promoted to support the decision-making process to better prepare for and adapt to the risks and opportunities of climate variability and change. The current market for CS is still in its early stages. In this paper, we report the findings from our recent investigation into the actual and potential market for CS for the Iberian Peninsula surf-tourism sector. Based on surfers' and surf companies' demands, it was found that an improved surfing climate service (herein, SCS) will have clear implications in the management of these tourism areas and provide insights into whether surfing activities may be successful. At the same time, such services can help to manage adaptive actions in regard to the impacts of climate change in surfing areas.
\end{abstract}

Keywords: climate services; tourism; surfing; waves; adaptation; mitigation

\section{Introduction}

Climate services (herein, CS) are promoted to support decision-making process in order to better prepare for and adapt to the risks and opportunities of climate variability and change [1]. According to the World Meteorological Organization (WMO), the role of CS in climate change mitigation and adaptation has been the subject of research, especially in the four priority areas of focus for the Global Framework for Climate Services (GFCS) [2]: (i) health [3,4]; (ii) agriculture [5-8]; and food security; (iii) water and energy; and (iv) disaster risk reduction. Examples of CS for agriculture can be found in Mali and Senegal, among other countries, where a new approach has been created to develop climate information services. This approach uses historical climate records, participatory decision-making tools, and forecasts to help farmers identify and better plan livelihood options suited to local climate features and farmers' varied circumstances [9]. In addition, several programs addressing climate services for improving public health can be found in Brazil [10] and Ethiopia [11].

Nevertheless, CS can also be developed for other sectors [12] such as tourism. For this sector, climate is identified as a factor of location; every economic activity requires a territorial base, and this applies to geographic spaces acting as supports for tourism activities. The kind of terrain in the support area also influences where activities are conducted. Climate is one of the geophysical elements that comprise geographic space [13], and it also works as a tourism resource. In this respect, climate is a basic resource for various activities that depend on the climate/weather, which can include sun and beach tourism, winter sports such as skiing and snowboarding, health tourism, and water sports [14]. 
Aligned with this, it has been affirmed that local climatology and the succession of different weather types influence the location of resorts, the calendar of tourism activities, the use and efficiency of the infrastructure, and the return on investments. Indeed, many resorts have prospered thanks to their ability to turn favorable local climatic conditions to their advantage [15-18].

The most widely applied approach for quantifying climatic resources is the Tourism Climate Index (TCI). The TCI was developed by Mieczkowski [19] and was designed to integrate the main climatic variables relevant to tourism into a single numerical index. Other tourism climate indexes have also been developed, including the Daily Comfort Index (CIA), the Daytime Comfort Index (CID), the Climate Index for Tourism (CIT), the Holiday Climate Index (HCI) [20], the Beach Comfort Index (BCI) [21] and the Modified Climate Index for Tourism (MCIT) [22].

Related to this, several studies have demonstrated the impact of climate on tourism demand. The information provided by such research has made it possible to identify optimal temperatures at travel destinations for different kinds of tourists and various tourism activities [23]. Climate change and tourist comfort on Europe's beaches during the summer have also been analyzed. The main results found that destination managers in Mediterranean tourism destinations should focus part of their attention on climate change impacts such as potential sea level rise and water availability. Furthermore, they should include environmental quality and diversification of activities in their deliberations. In non-Mediterranean regions, a promising strategy may be to focus on short- and mediumdistance visitors who can take advantage of new opportunities for beach tourism and explore the merits of seasonal climate forecasting [24].

Climate change can affect tourism. When considering the implications of an increase of $2{ }^{\circ} \mathrm{C}$ in global warming for European summer tourism, the main results showed that climate change will positively affect Central and Northern Europe, thus increasing the potential for further economic development in this direction. Mediterranean countries, by contrast, stand to lose favorability as tourism destinations during the hot summer months but will tend to gain favor during the early- and late-summer seasons [25]. Therefore, improved climate services will become even more vital for travelers, the travel and tourism industries, and destinations and will be required to adapt services and activities to meet the challenges of climate change in an economically, socially, and environmentally sustainable manner [22].

In regard to sun and beach tourism, beaches are the principal attraction. Quantitative and qualitative assessments illustrate that most of the world's sandy shorelines are in retreat [26]. In this framework, it has been shown that coastal zones are particularly in need of climate services for adaptation. This field of research has analyzed how annual to multidecade sea level projections can be used within coastal climate services [27].

Climate and weather conditions for outdoor recreation construct the basis to identify which activities are viable in certain territories and moments, and which are not [28].

Surf, snow, wind, and white-water provide natural resources for adventure tourism. Both the resources themselves and their access for tourism are dependent on weather and, hence, are affected by climate change [29]. As defined by different authors, surf tourism involves travel and temporary stays undertaken by surfers with the primary expectation of surfing waves [30,31]. Such travel includes at least one night away from the region of their usual domicile. The growth of surfing activities and surf tourism has gained significant attention in academia. The Surf Resource Sustainability Index (SRSI) was developed as a conceptual model to study the sustainability of surf-tourism sites. It focuses on the importance of social, economic, environmental, and governance factors in the conservation process [32]. Referring to studies about wave climates and surfing, Espejo et al. [33] studied the spatial and temporal variability of surfing resources around the world. Peñas del Aro [34] identified the distribution of surfing days in Mallorca, and Boqué et al. [35] defined the expected number of surfing days per year on the Iberian Peninsula. 
Some research has identified behavioral market segments among surf tourists based on past destination choice. One study was conducted through an online survey, and the results show six market segments that take into consideration different ages, various levels of surfing ability, length of stay, preferred wave type, and the regularity of undertaking trips with the aim of surfing at the chosen destination [36]. Other studies have examined the natural component of seasonality in relation to surf tourism, using survey responses collected globally and analyzing how surfers report using forecasts to make travel decisions. In addition, occupancy data is analyzed in relation to surf-forecast data to empirically assess intraseasonal fluctuations. The results found that most international travel is booked months in advance based on climatic factors [37]. Works focusing on identifying surfers' profiles have also been explored in the Mentawai Islands of the western coast of Sumatra [38].

The need to understand how surf tourism works is aligned with the need for surfbreak preservation. Indeed, Reiblich, who researches legal and policy implications of coastal adaptation, has stated that surfbreaks include three components: the submerged lands under the wave zone; a wave corridor that allows an unimpeded right of way for swells to reach the wave zone; and beach access. In this sense, sufficient surfbreak protection requires that policymakers employ a strategy that takes all three components into consideration [39,40]. In some surf spots such as the Bahía de Todos Santos World Surfing Reserve, surfbreak preservation has been applied. In addition, some studies in Peru, Chile, and the US have focused on the link between surfing and marine conservation, thus highlighting representative surfbreaks and the need for their protection not only for their value to surfers but also for the ecosystem services they provide, as well as other benefits for marine conservation [40].

In the field of CS for surfing, studies about the efficient delivery of forecasting to a nautical sports mobile application (hereafter, app) with semantic data services have demonstrated that weather and sea-related forecasts provide crucial insights for the practice of nautical sports such as wave surfing and kite surfing. Moreover, mobile devices are appropriate interfaces for the visualization of meteorology and operational oceanography data [41]. Scott et al. [22] found that private-sector climate service providers have been innovators in the use of emerging communication technologies designed to deliver specialized climate information to tourists and other tourism-sector end-users. Several examples can be found on weather applications tailored to specific tourism-related activities such as skiing, surfing (e.g., the Oakley Surf Report) and fishing. Meanwhile, several items have been designed to track surfing sessions and to register different variables. Pontes Caselli et al. [42] developed a systematic proposal for UX-centered mobile apps for tracking performance in sports through an app in recreational surfing. Another case of a technological design for surfing is the creation of Smart Fin, which records temperatures and GPS for surf science. In addition to the creation of this technology, a survey was designed to identify groups within the surfing community that would surf for science [43].

A range of communication channels exists for the delivery of climate information to tourists and the tourism sector. Successful attempts have been made to provide understandable, familiar, and consistent international meteorological information that can be used by tourists, but how climate information is communicated to tourists and tourism subsectors remains largely unexplored [22].

As stated, while several studies about surfing forecast apps and surfbreak preservation are available in the literature [44], we are not aware of any study that has designed a surfing-climate service (hereafter, SCS). As previously discussed, the relationship between climate, weather, and tourism must be understood so that tourism planning can be more effective. In this regard, CS can be a tool for achieving effective surf-tourism planning. For this reason, this paper strongly focuses on the design of an SCS tailored for surfers and other surf tourism-sector end-users on a regional scale, specifically, in the Iberian Peninsula framework. 
The creation of CS for surf tourism is still in an early and premature stage of development. For this reason, the present study aims to establish the basis of the SCS design, specifically by understanding which meteorological and climatological information is requested for a better surfing experience. In this research, we pursue the following objectives: (1) to explore and define what meteorological and climatological information is used nowadays; (2) to discover which meteorological and climatological information can be improved for a better surfing experience; (3) to understand what environmental problems negatively affect surf activities; and (4) to understand surfing tourism flows on the Iberian Peninsula.

\section{Data and Methods}

\subsection{Survey Description and Target Audience}

This research created an online survey with the aim of better understanding how a surfing-climate service (SCS) should be designed for surfers and other surf-tourism sector end-users for surfing on the coast of the Iberian Peninsula. In this regard, the study area covers the coast of the Iberian Peninsula, located in the southwest corner of the European continent. The countries that comprise the peninsula are Spain, Portugal, France, Andorra, and the United Kingdom (Gibraltar). The target population corresponds to surfers older than 16 years of age who have surfed somewhere on the Iberian Peninsula.

Currently, there is no identified number of how many people actually engage in surfing activities; as Esparza [45] presented, this is because many surfers are not registered in any federation, and in some cases, surfers practice this sport only sporadically, making it difficult to identify them as tourists. For the purposes of this study, we will identify surf tourism using two criteria: (1) surfers stay at a location for at least one night that differs from their usual place of residence in order to surf, and (2) the travel is conducted by active surfers, meaning experts and other practitioners of the sports as well as beginners who travel with the main purpose of surfing. For this reason, the target population is considered infinite for calculating the sample (Equation (1)). We have obtained 470 samples; as there are no previous studies of prevalence in this field, values of probability are considered the same: $p(0.5)$ and $q(0.5)$. We establish $z=95 \%$ through Equation (1) to calculate the value of $d(4.52 \%)$.

$$
\begin{gathered}
d=\sqrt{\frac{z^{2} p q}{n_{s}}} \\
d=\text { maximum allowable error } \\
z=\text { level of confidence } \\
p=\text { probability of success } \\
q=\text { probability of failure } \\
n_{s}=\text { sample number }
\end{gathered}
$$

First, a pilot survey was launched [46] on SCS; then, the study survey was revised and redesigned according to the answers and feedback from the pilot survey.

Secondly, to achieve the sample, surveys were distributed to surfers via social networks, i.e., Twitter, Instagram, and Facebook, and a surfing radio program. For this reason, results may be biased, and previous parameters should be taken as approximate values. The survey distribution was conducted from 19/05/2020 to 17/10/2020. It included 34 questions in different formats: open-ended, closed-ended, rating, and multiple choice (Table 1). The text for the survey can be found in the Appendix B. 
Table 1. Format of survey questions and topic of interest.

\begin{tabular}{|c|c|c|}
\hline Question Number & $\begin{array}{c}\text { Format of Survey } \\
\text { Question }\end{array}$ & Topic of Interest \\
\hline 0 & Filter & Ever surfed on the Iberian Peninsula \\
\hline 1 & Closed-ended & Demographic information \\
\hline $2,3,4$ & Open-ended & Demographic information \\
\hline 5,16 & Closed-ended & Behavior information \\
\hline 6 & Open-ended & Surfer profile \\
\hline $7,8,9$ & Closed-ended & Surfer profile \\
\hline 10 & Open-ended & Local surf spot \\
\hline 11 & Multiple choice & Environmental changes \\
\hline 12 & Open-ended & Environmental changes \\
\hline 13 & Closed-ended & Surfing tourism mobility behavior \\
\hline 14 & Open-ended & $\begin{array}{l}\text { Surfing tourism mobility behavior } \\
\text { Request for }\end{array}$ \\
\hline $15,19,21,25$ & Multiple choice & $\begin{array}{c}\text { meteorological/climatological } \\
\text { information }\end{array}$ \\
\hline 17 & Rating & $\begin{array}{l}\text { meteorological/climatological } \\
\text { information }\end{array}$ \\
\hline $18,22,24$ & Closed-ended & $\begin{array}{c}\text { Request for } \\
\text { meteorological/climatological } \\
\text { information }\end{array}$ \\
\hline 20,23 & Open-ended & $\begin{array}{c}\text { Request for } \\
\text { meteorological/climatological } \\
\text { information }\end{array}$ \\
\hline 26 & Open-ended & $\begin{array}{l}\text { The perceptions of meteorological and } \\
\text { climatological information use by } \\
\text { entrepreneurs, managers or workers at } \\
\text { surf schools or similar }\end{array}$ \\
\hline 27 & Multiple-choice & $\begin{array}{l}\text { The perceptions of meteorological and } \\
\text { climatological information use by } \\
\text { entrepreneurs, managers or workers at } \\
\text { surf schools or similar }\end{array}$ \\
\hline $28,29,30,31,32$ & Closed-ended & $\begin{array}{l}\text { The perceptions of meteorological and } \\
\text { climatological information use by } \\
\text { entrepreneurs, managers or workers at } \\
\text { surf schools or similar }\end{array}$ \\
\hline 33,34 & Open-ended & Other comments \\
\hline
\end{tabular}

\subsection{Survey Analysis}

The survey analysis allowed the identification of different facets that will contribute to the design of the SCS. These aims are (1) the identification of preferred sea information to assess decision-making before surfing; (2) the identification of future needs for surf-forecast delivery; (3) to understand surfers' perceptions of the environmental problem; and (4) to understand surfing tourism locations on the Iberian Peninsula. Each facet is related to the specific topic. Using all the information gathered, it is possible to design an SCS prototype (Figure 1). 


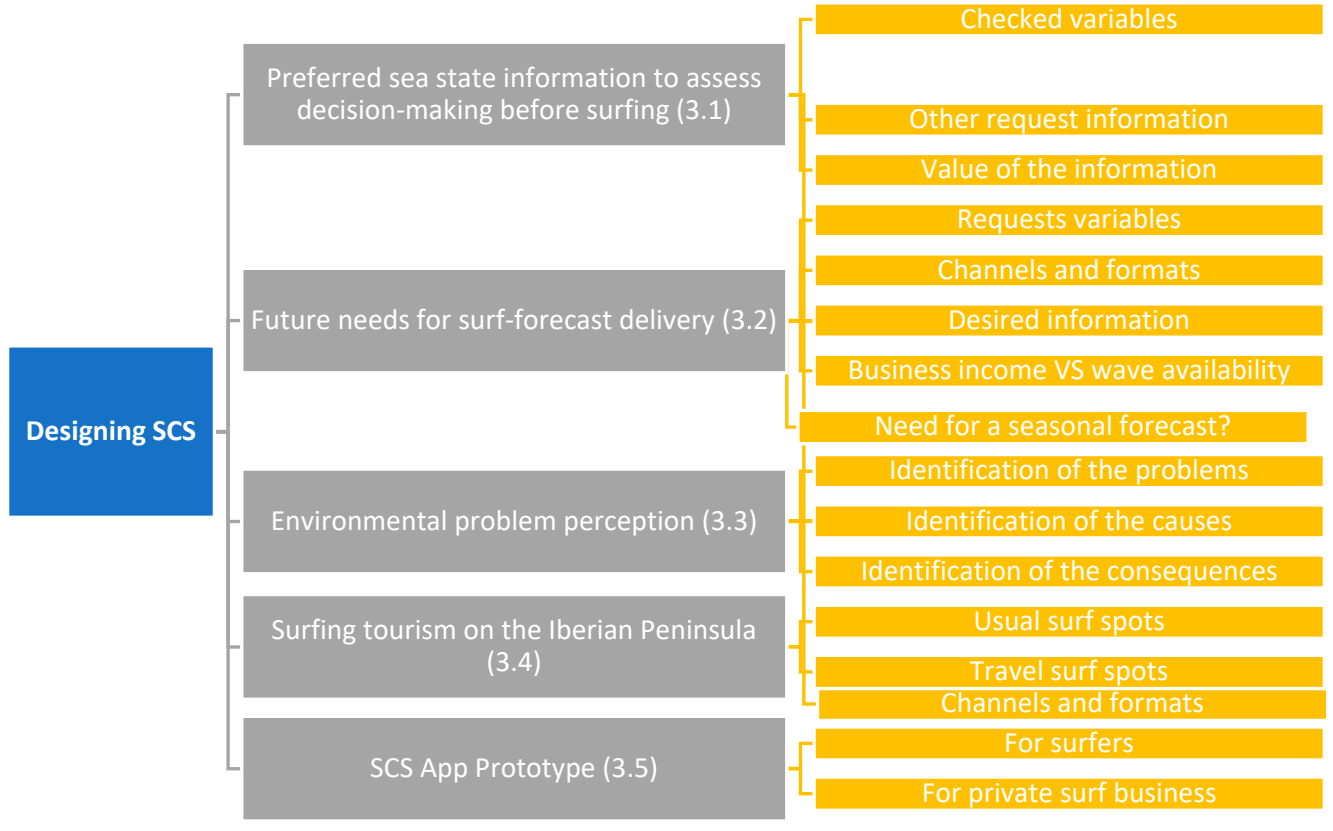

Figure 1. Procedure for designing a prototype of a Surfing Climate Service.

\section{Results}

The following subsections present the results of the SCS survey and a discussion of the SCS prototype design.

They include: (Section 3.1) preferred sea-state -surfing conditions-information to assess decision-making before surfing; (Section 3.2) future needs for surf-forecast delivery; (Section 3.3) environmental problem perception; (Section 3.4) usual surf spots and surf tourism on the Iberian Peninsula; and (Section 3.5) an SCS App Prototype.

In our survey, the male gender represents $75.11 \%$ and female $24.89 \%$; the main nationalities are Spanish (66.52\%), and Portuguese (17.29\%) followed by others (16.19\%). Ages are distributed in different intervals: (16-25) 26\%; (25-35) 38.90\%; (35-45) 24.95\%; (45-55), $8.46 \%$, and above 55 years, $1.69 \%$ of the respondents. Summary of Survey Responses can be found in Appendix B.

\subsection{Preferred Sea-State Information to Assess Decision-Making before Surfing}

Before going surfing, $84.47 \%$ of surfers always seek information, $15.53 \%$ sometimes seek information, and $0.00 \%$ never seek information. Surfers identify two sources of wave prediction: forecasts and nowcasts. The use of forecasts represents most cases; then, nowcasts are used to verify a previously checked forecast. Therefore, nowcasting works as a source of swell confirmation. Thanks to the results of the survey, it is possible to know which kind of wave prediction surfers prefer and use most frequently (Figure 2). In this sense, a ranking about the information consulted before surfing is presented (in which 1 is the lowest and 5 is the highest value, meaning 5 represents more accurate information). This ranking shows seven different categories ( $Y$ axis) in which different sources of sea-state information can be identified (primary sources forecasts, nowcasts, and secondary sources). As shown, the most preferred sources are internet sites with forecasts (3.98 stars), webcam access (3.71 stars), and information from friends / family (3.54 stars). These are followed by information from buoys in real-time (3.30) and isobaric maps (3.03). The least-preferred source of information is the from surf school/coach (2.59) and social networking sites (2.57). This fact shows that sea-state information quality may be better from the surfers' perspectives, so no evaluations are close to 5 . 


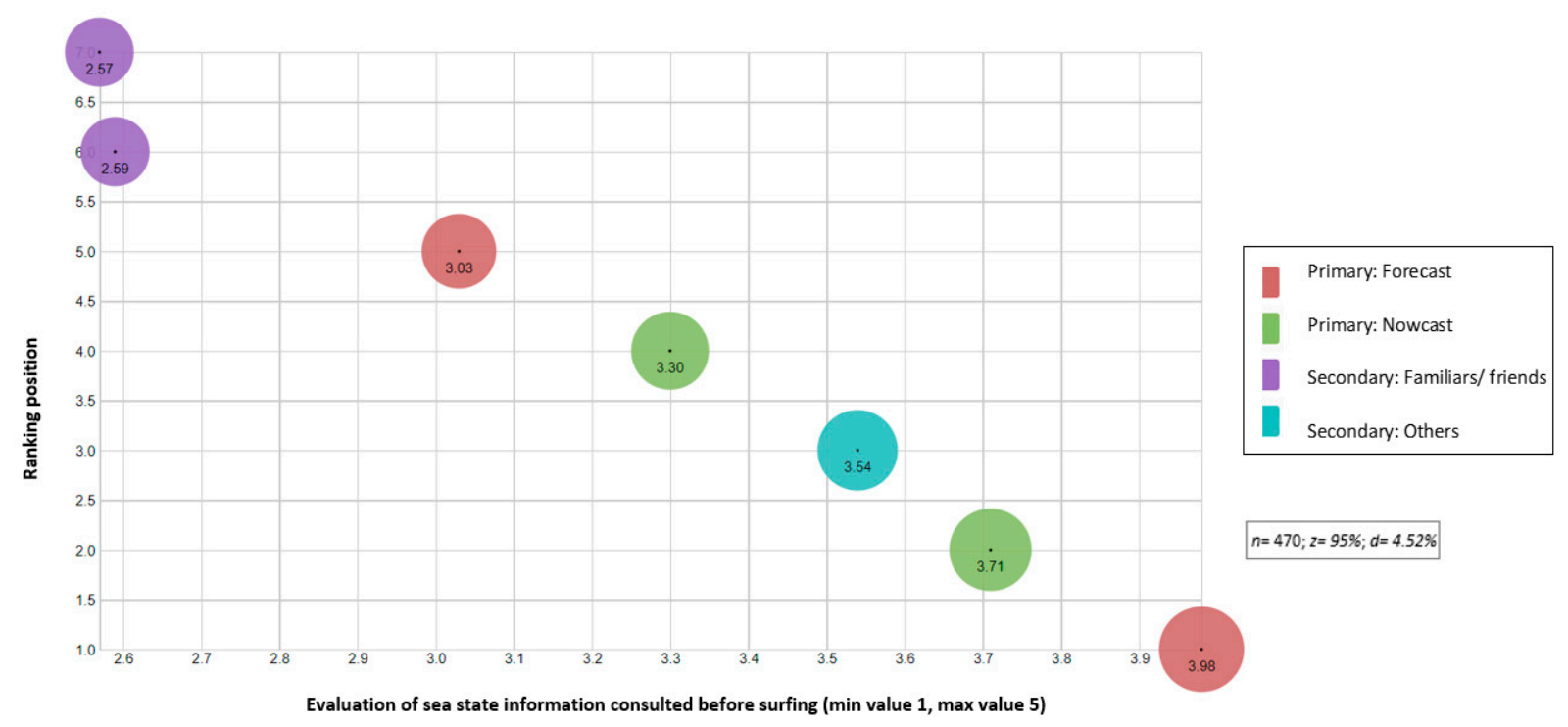

Figure 2. Ranking of sea-state information consulted before surfing.

To plan quality surfing sessions, every surfer needs to be familiar with the everchanging state of the ocean. It is known that surfers consult a great variety of sources to anticipate wave conditions in various surf spots. The sources can be found on different forms of communication including websites and applications for mobile devices or both. Table 2 presents actual surf-forecast delivery on websites and apps, which represent the combination of the most frequently consulted channels. The range of forecasting for most of these services is 10 days as the maximum; for longer-term forecasts, surfers must purchase a premium version or a forecast app still in beta version such in Todosurf. All the apps and websites are focused mainly on forecasting the following variables: wave height, wave period, wind speed, wind direction, and differentiation between primary swell and other swells. Depending on the source, other complementary variables may also be reported, such as surf-quality rating, wave energy, and tidal schedules among others. The prediction models differ depending on resources; some allow making comparisons with different prediction models and others do not. Among these resources, there are some specifically designed to address surfers' requirements, including Todosurf, Wisuki, Magicseaweed, MedSwells, and Surfline. Others are specifically designed for windsurfing and include Windfinder and Windguru; they may also report some information useful for surfers that, in some cases, may not be shown in other resources. There is also Windy, which is not specifically designed for sports-related predictions but offers information relevant to surfing predictions.

Other resources can be found only on website channels. Table 3 shows that, in general terms, the range of prediction is shorter than for the resources described in Table 2. In the table below, nowcasting is present, and the most common prediction range is between three and seven days. The information for SurfMediterraneo presents a wider range. The main variables forecasted are similar to those previously presented. In this kind of resource, there are also maritime forecasts designed by local meteorological services, such as those from MeteoGalicia and Aemet. It is interesting to highlight the Camaramar website, which not only provides sea-state forecasts but also offers active tourism information. 
Table 2. Websites and app channels for sea-state information for surfing.

\begin{tabular}{|c|c|c|c|c|}
\hline $\begin{array}{l}\text { Name of The } \\
\text { Resource }\end{array}$ & Prediction Model & Time of Prediction & Variables & Comments \\
\hline Todosurf & Nonspecified & $\begin{array}{l}7 \text { days, } 14 \text { days } \\
\text { (new) }\end{array}$ & $\begin{array}{l}\text { Wave height, wave direction, wave } \\
\text { period, energy, wind intensity, } \\
\text { wind direction. } \\
\text { Summary of wind waves, swell 1, } \\
\text { swell } 2 \text { with the following variables: } \\
\text { wave height, wave period, and } \\
\text { wave direction. } \\
\text { Quality rating. }\end{array}$ & $\begin{array}{l}\text { In the same app/website } \\
\text { buoy's data, wind map, and } \\
\text { waves map are present from } \\
\text { Puertos del Estado. } \\
\text { The site allows configuring } \\
\text { alarms for the favorite } \\
\text { surf-spots. }\end{array}$ \\
\hline Wisuki & Nonspecified & 7 days & $\begin{array}{l}\text { Wind (direction, average, gust), waves } \\
\text { (direction, height, period), and tides. }\end{array}$ & $\begin{array}{l}\text { This app is very visual and } \\
\text { interactive with satellite } \\
\text { images joined with graphs. In } \\
\text { the same app/website weather } \\
\text { information is shown. }\end{array}$ \\
\hline Magicseaweed & $\begin{array}{l}\text { NOA WAVEWATCH III, } \\
\text { PROTEUS GLOBAL }\end{array}$ & $\begin{array}{c}7 \text { days, } \\
16 \text { days (pro) }\end{array}$ & $\begin{array}{l}\text { Surf height, wind gusts, wave } \\
\text { direction, wind intensity and } \\
\text { direction, tides. } \\
\text { Quality rating. } \\
\text { Information about primary and } \\
\text { secondary swell can be shown. } \\
\text { Wind direction, wind average, wind } \\
\text { gust, wave height (primary and } \\
\text { secondary swell), wave period. }\end{array}$ & $\begin{array}{l}\text { In the same app/website } \\
\text { weather information is shown. } \\
\text { Webcam access with the } \\
\text { pro version. } \\
\text { It is possible to consult the sea } \\
\text { stat historic of the spots. } \\
\text { General weather app where } \\
\text { there is a specific section for } \\
\text { surfing activity. }\end{array}$ \\
\hline Windguru & $\begin{array}{l}\text { GFS 13, AROME 1.3, } \\
\text { AROME 2.5, } \\
\text { Zephr-HD3, Zephr-HD4, } \\
\text { WRF 9, ICON 7, } \\
\text { HIRLAM 7.5, Zephr-HD } \\
\text { 9, WRF 27, ICON 13, } \\
\text { GDPS 15 }\end{array}$ & 10 days & $\begin{array}{l}\text { Wind speed, wind gust, wind direction, } \\
\text { temperature, cloudiness, tides. } \\
\text { Quality rating (in this case is } \\
\text { for windsurfing). }\end{array}$ & $\begin{array}{l}\text { There is a pro version that } \\
\text { allows access to more maps } \\
\text { and models which helps to } \\
\text { have a more accurate } \\
\text { wind prediction. }\end{array}$ \\
\hline Windfinder & $\begin{array}{l}\text { GFS and Superforecast } \\
\text { (This mixes GFS + } \\
\text { horizontal information) }\end{array}$ & 7 days & $\begin{array}{l}\text { Wind direction, wind speed, wind gust, } \\
\text { cloudiness, kind of precipitation, air } \\
\text { temperature, sea level pressure, wave } \\
\text { direction, wave height, and } \\
\text { wave period. } \\
\text { Wind chill, relative humidity } \\
\text { (in Superforecast) }\end{array}$ & $\begin{array}{l}\text { The site also provides } \\
\text { statistical historic of } \\
\text { some variables. } \\
\text { The site presents some } \\
\text { surf-spot webcams. }\end{array}$ \\
\hline Medswells & $\begin{array}{l}\text { From FNMOC wave } \\
\text { watch } 3 \text { model }\end{array}$ & 3 days & $\begin{array}{l}\text { Isobaric and surge maps- } \\
\text { Wave height, wave direction, and } \\
\text { wave period. } \\
\text { It also presents variables from wind } \\
\text { swell and sea swell and quality rating. }\end{array}$ & $\begin{array}{l}\text { The site also allows surf-spot } \\
\text { webcams access and configure } \\
\text { alarms for the favorite } \\
\text { surf-spots. }\end{array}$ \\
\hline Surfline & LOLA & $\begin{array}{c}2 \text { days, } \\
17 \text { days premium }\end{array}$ & $\begin{array}{l}\text { Wave height, direction, and period } \\
\text { (primary, secondary and tertiary swell). } \\
\text { Wind direction and intensity. Tide } \\
\text { hours and weather conditions. }\end{array}$ & $\begin{array}{l}\text { The site also allows access to a } \\
\text { global navigator where there } \\
\text { are regional waves, local } \\
\text { waves, buoys observations, } \\
\text { and Surfline charts around } \\
\text { the world. } \\
\text { The site also informs about } \\
\text { specific surf conditions. }\end{array}$ \\
\hline
\end{tabular}

Other resources are available only through the app channel (Table 4); this is the case for Imar and Line App. The first one provides information from Puertos del Estado but is not specifically designed for surfing. However, it offers interesting variables for surfers, and it is possible to search conditions by their list of beaches in Spain and then consult the "nowcast and forecast up to three days" for specific maritime and weather variables. Conversely, Lineapp is designed for surfing with an innovative design that allows not only searching sea-state information but also offers an opportunity to create a community with local surfers, surf travelers, and surf schools. 
Table 3. Website channels for consulting sea-state information for surfing.

\begin{tabular}{|c|c|c|c|c|}
\hline $\begin{array}{l}\text { Name of the } \\
\text { Resource }\end{array}$ & Prediction Model & Time of Prediction & Variables & Comments \\
\hline Surf forecast & Nonspecified & 7 days & $\begin{array}{l}\text { Significant wave height map. } \\
\text { Wave height, wave direction, wave } \\
\text { period, energy, wind direction, } \\
\text { wind intensity, wind state, } \\
\text { and tides. } \\
\text { Quality rating. }\end{array}$ & $\begin{array}{l}\text { Wave height is in the open sea. } \\
\text { In the same app/website } \\
\text { information about weather, } \\
\text { advanced surf, local } \\
\text { wavefinder, and global } \\
\text { wavefinder are shown. }\end{array}$ \\
\hline Puertos del estado & $\begin{array}{c}\text { Wind modelized from } \\
\text { Hamnnie-Arome, then } \\
\text { wave data is modelized } \\
\text { by WAM }\end{array}$ & 3 days and nowcast & $\begin{array}{l}\text { Wind speed, wind direction, wave } \\
\text { height, wave period, water } \\
\text { temperature, atmospheric pressure, } \\
\text { salinity level. }\end{array}$ & $\begin{array}{l}\text { It is possible to consult } \\
\text { historic data. }\end{array}$ \\
\hline Surfmediterraneo & $\begin{array}{c}\text { Aemet, Meteocat, } \\
\text { FNMOC, UOA } \\
\text { Mediterranean, DICCA, } \\
\text { laMMA, GFS, MetOffice }\end{array}$ & $\begin{array}{l}7 \text { days, } 9 \text { days } \\
\text { (isobaric maps), } \\
16 \text { days } \\
\text { (wind maps) }\end{array}$ & $\begin{array}{l}\text { There is a link to the table of } \\
\text { Puertos del Estado: wind speed, } \\
\text { wind direction, wave height, wave } \\
\text { direction, wave period. Secondary } \\
\text { and primary swell variables. }\end{array}$ & $\begin{array}{c}\text { Webcams. } \\
\text { This website collects different } \\
\text { cartography about the forecast } \\
\text { of different Meteo services for } \\
\text { different variables. }\end{array}$ \\
\hline Surfcantabria.com & $\begin{array}{l}\text { See Windy information } \\
\text { See Windguru } \\
\text { information }\end{array}$ & $\begin{array}{l}\text { See Windy } \\
\text { information } \\
\text { See Windguru } \\
\text { information }\end{array}$ & $\begin{array}{l}\text { This website collects Windguru } \\
\text { forecast and Windy forecast in a } \\
\text { visual way. }\end{array}$ & $\begin{array}{l}\text { The website collects links to } \\
\text { other sources of forecast } \\
\text { (Magicseaweed, storm surf, } \\
\text { aemet ... ) with link to } \\
\text { surf-spot webcams. }\end{array}$ \\
\hline Camaramar & $\begin{array}{l}\text { Not applicable. } \\
\text { Nowcast }\end{array}$ & Nowcast & $\begin{array}{c}\text { Specification of surf-spot } \\
\text { localization, better wind, better } \\
\text { season, and surf-spot orientation }\end{array}$ & $\begin{array}{l}\text { This website provides a } \\
\text { webcam for different } \\
\text { surf-spots as well it links to } \\
\text { active tourism offers }\end{array}$ \\
\hline Fnmoc & $\begin{array}{l}\text { From FNMOC wave } \\
\text { watch } 3 \text { model }\end{array}$ & 3 days & $\begin{array}{l}\text { Significant wave height and } \\
\text { direction, swell wave height and } \\
\text { direction, wind wave height and } \\
\text { direction, swell wave period and } \\
\text { direction, wind wave period and } \\
\text { direction, peak wave period and } \\
\text { direction, white cap probability. }\end{array}$ & Maps of prediction. \\
\hline Meteogal & Nonspecified & 3 days & $\begin{array}{l}\text { Tide time, sky state, wind direction } \\
\text { and intensity, sea state, visibility, } \\
\text { wave height direction and height, } \\
\text { air temperature, water } \\
\text { temperature, and maximum } \\
\text { UV index. }\end{array}$ & $\begin{array}{l}\text { In MeteoGalicia there is a } \\
\text { maritime prediction section. }\end{array}$ \\
\hline SurfCatalunya & $\begin{array}{l}\text { From FNMOC wave } \\
\text { watch } 3 \text { model }\end{array}$ & 3 days & See Medswells variables. & $\begin{array}{l}\text { The website also presents } \\
\text { some surf-spot webcams. } \\
\text { The forecast section uses } \\
\text { Medswells information. }\end{array}$ \\
\hline Aemet & Nonspecified & 5 days & $\begin{array}{c}\text { Map of wind sea and wave sea } \\
\text { including wave direction } \\
\text { and height. }\end{array}$ & $\begin{array}{l}\text { In Aemet there is a coast } \\
\text { maritime prediction section. }\end{array}$ \\
\hline
\end{tabular}

The main channels of communication (arranged by use) are apps or websites; in a small number of cases, TV weather forecasts are also used.

Referring to the time in advance that a forecast is checked, it has been found that surfers consult the information one day in advance $(67.66 \%)$, two to three days in advance $(67.23 \%)$, and on the same day $(66.38 \%)$. They also check it $4-7$ days in advance $(45.53 \%)$. Further forecasts are less often consulted; specifically, $6.60 \%$ consult information two weeks in advance, $0.85 \%$ one month in advance, $0.21 \%$ one year in advance. Conversely, predictions three months in advance are not consulted. All participants checked the forecast somewhere. 
Table 4. App channels to consult sea-state information for surfing.

\begin{tabular}{|c|c|c|c|c|}
\hline $\begin{array}{l}\text { Name of The } \\
\text { Resource }\end{array}$ & Prediction Model & Time of Prediction & Variables & Comments \\
\hline Lineapp & Nonspecified & 7 days & $\begin{array}{l}\text { Wave height, direction, } \\
\text { and period. Wind } \\
\text { intensity and direction. } \\
\text { Air temperature and } \\
\text { cloudiness. } \\
\text { Quality rating. }\end{array}$ & $\begin{array}{l}\text { The app includes surf alerts, } \\
\text { social and news feed. The app } \\
\text { helps to better communication } \\
\text { between surfers and surf schools. } \\
\text { The app also includes tailored } \\
\text { information regarding your } \\
\text { profile-surfer or surf school. } \\
\text { The app also informs users about } \\
\text { spot details-kind of spot, } \\
\text { bottom type, best swell, best } \\
\text { wind, wave type, and spot level. }\end{array}$ \\
\hline Imar & $\begin{array}{l}\text { Aemet (wind), } \\
\text { Puertos del Estado } \\
\text { (other variables) }\end{array}$ & 3 days and nowcast & $\begin{array}{l}\text { Wave height, wave } \\
\text { direction, wave period, } \\
\text { sea level. Wind } \\
\text { direction wind intensity. } \\
\text { There are the same } \\
\text { variables available in } \\
\text { real-time. } \\
\text { Weather alert. }\end{array}$ & $\begin{array}{l}\text { The main information of sea } \\
\text { state from Puertos del Estado in } \\
\text { one practical app. }\end{array}$ \\
\hline
\end{tabular}

The main parameters checked in the surfing forecast-multiple choice option in the survey-(Figure 3 ) are wave height $(91.91 \%)$, wave period $(89.79 \%)$, wind direction $(85,74 \%)$, wind intensity $(79.36 \%)$, and energy (51.28\%). Other parameters represent $13.19 \%$ and include information such as swell direction (primary and secondary swell direction), water temperature, wave formation, tide schedule, and meteorological maps to see where low pressure and high pressure are originating from and their trajectory. Atmospheric pressure is consulted in $11.70 \%$ of cases, and $0.00 \%$ do not consult a forecast.

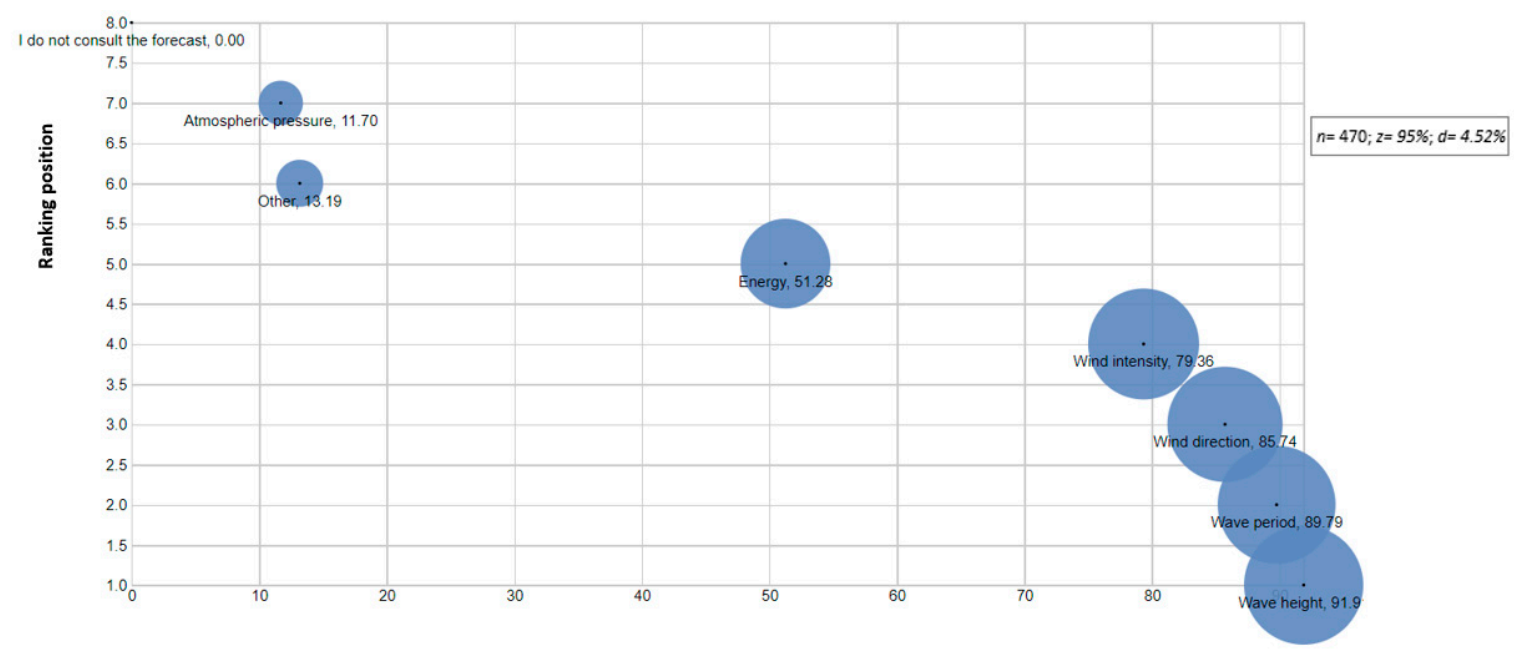

Percentage of surfers that consult specific variable (\%)

Figure 3. Ranking of variables about sea-state information consulted before surfing.

The results show a wide variety of resources that help surfers to assess their decisions when planning a surfing trip (Figure 4). Blue dots represent the percentage of surfers that consult specific variables. From this diversity, we can define the following types: designed for surfers, designed for windsurfers, ocean/sea sensors, and weather services. The sources designed for surfers report all the necessary information tailored for specific 
surfer needs. The sources designed for windsurfers give them better knowledge about wind forecasts than the sources designed specifically for surfers. This is because the main resource needed for windsurfing is wind, and for surfing it is waves. Nevertheless, both variables are relevant for both sports. The sources designed for surfers and windsurfers act mainly as forecasts.

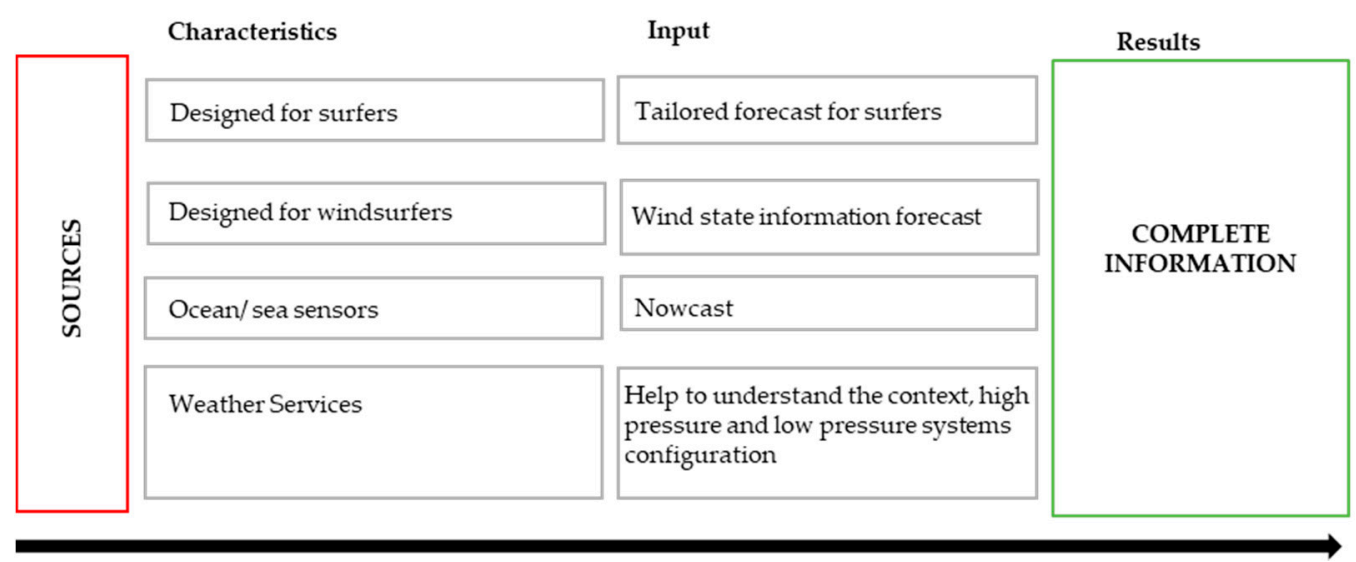

Figure 4. Websites and app channels for sea-state information for surfing.

Next, weather services help surfers better understand the context in which their desired meteorological variables are developed. Thanks to that source, surfers can understand which generation systems are in action, where they are located, and where are they going. Then, it is possible to interlink the generation systems (high and low pressures) with the behavior of the required variables for surfing such as wave height, wave period, wave direction, wind direction, and wind intensity. Finally, ocean/sea sensors work as nowcast systems that help to validate all the previous information consulted. Depending on the surfers' profiles, they check all kinds of sources, several, or just one.

\subsection{Future Needs for Surf-Forecast Delivery}

Previously, we have observed which resources currently exist that provide the required sea-state and weather information for surfers. We have shown that there is a wide range of information tailored and designed in different ways and presented through multiple channels. We also know which variables surfers require more in their consulted forecasts that will help them figure out how a surfing session will be. Next, it is necessary to present the future needs of surf-forecast delivery for surfers and private surfing businesses. In the following sections, we discuss what can and should be improved in actual forecasts and what surfers' perceptions are in regard to the need for seasonal forecasting related to surfing.

\subsubsection{Future Needs for Surf-Forecast Delivery for Surfers}

The main results in regard to the future needs for surf-forecast delivery are structured by four fundamental pillars (Figure 5): (1) perception about reality, (2) requirements, (3) possible solutions, and (4) results.

Perceptions about reality from surfers identify that wave approximation from the fetch area to the shore work differently depending on whether the fetch is generated in the ocean or in the sea. This is the case for the Iberian Peninsula, where waves in northern and western surf spots (Atlantic Ocean) have a lot of space to travel once they arrive at the shore; in this case, the fetch can be monitored with more anticipation than the surfing conditions on the eastern shore (Mediterranean Sea). On the eastern shore, the optimal conditions for surfing are usually created by fetch generation originally located close to the shore; then, there is less space and time to travel until the waves reach the shore, and thus the requirements for prediction are quite different. Surfers affirm that each surf spot 
is unique and that wave predictions for surfing can be improved. They also state that a number of parameters influence wave availability.

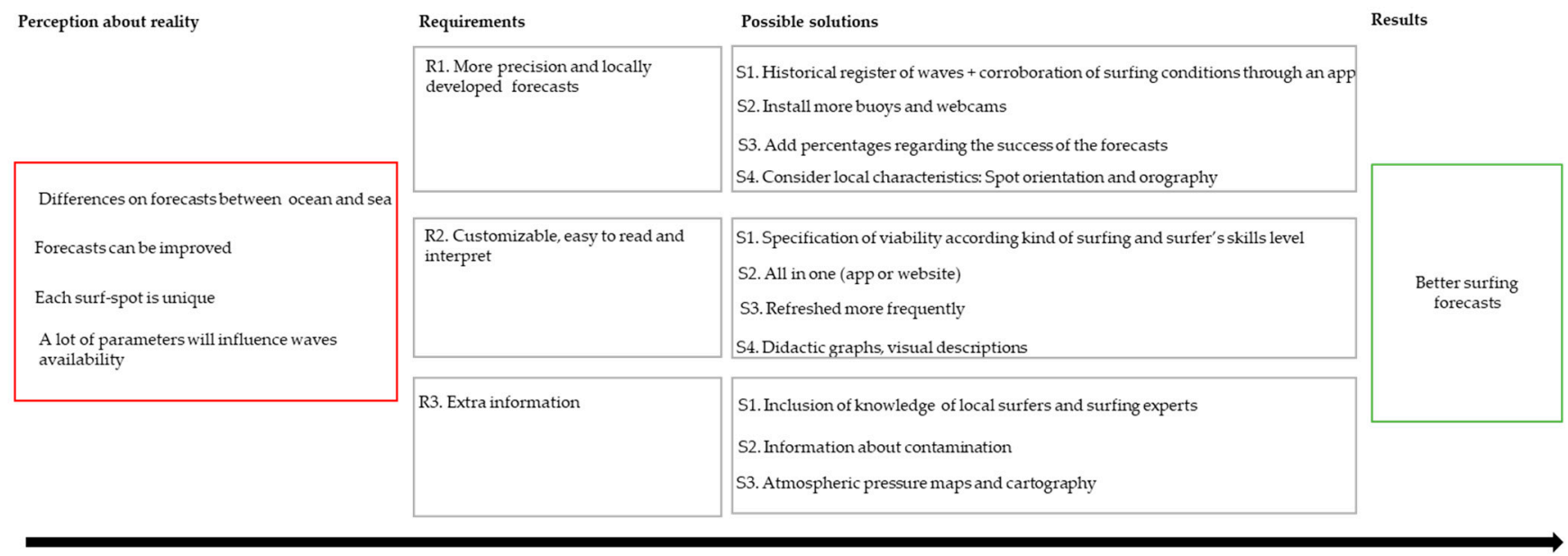

Figure 5. Suggested improvements for surfing forecasts from surfers' perspectives.

Therefore, different requirements are presented from the surfers' perspectives: (R1) there is a need for more precision and locally developed forecasts, and (R2) forecasts should be customizable and easy to read and interpret. Surfers also emphasize the transversality of information that they require; and thus, (R3) they would like to have additional information in their SCS such as contamination state and sea-bank locations.

In this vein, surfers also identify possible solutions to address all these requirements. Regarding R1, possible solutions could be: (S1-R1) to manage the historical register of waves and corroborate surfing conditions through an app and establish patterns for specific areas; (S2-R1) to install more buoys and webcams; (S3-R1) to add percentages regarding the success of the forecasts; and (S4-R1) to consider local characteristics such as spot orientation and orography. R2 can be addressed by the following solutions: (S1-R2) specification of surfing viability according to kind of surfing and surfer's skills level; (S2-R2) all in one app or website; (S3-R2) information that is refreshed more frequently; and (S4-R2) didactic graphs and visual descriptions. R3 can be improved by: (S1-R3) the inclusion of knowledge of local surfers and surfing experts; (S2-R3) information about contamination in surf spots; and (S3-R3) inclusion of atmospheric pressure maps and cartography. From surfers' perspectives, if all these requirements are met, together they will make it possible to have better surfing forecasts.

Surfers were asked if they would use seasonal forecasts. The results show that $57.66 \%$ think that being able to check a seasonal forecast would be useful for them in planning surfing trips; conversely, $20.43 \%$ do not think they would use a seasonal forecast. Other surfers, $13.62 \%$, do not know if this kind of forecast would be useful for them or not, and $8.09 \%$ have other opinions about this. The majority doubt the possibility of producing worthwhile seasonal surfing forecasts.

The required channels for receiving seasonal forecasts for surfers are apps for smartphones $(64.47 \%)$, websites $(45.11 \%)$, newsletters in mail accounts $(9.15 \%)$, and SMS $(6.81 \%)$; others were not interested in seasonal forecasts or gave other answers $(17.87 \%)$.

\subsubsection{Future Needs for Surf-Forecast Delivery for Private Surfing Businesses}

In the case of surfing businesses, the preferred channels for receiving surfing forecasts for companies and surfing instructors are apps for smartphones $(47.88 \%)$, websites $(33.33 \%)$, newsletters in mail accounts $(7.88 \%)$, and SMS (5.45\%); $1.82 \%$ were not interested in seasonal forecasts.

Private surfing businesses were asked about the value of seasonal surfing forecasts. The results show that usability can be profitable for deciding where to locate the activity 
(50\%), for managing clients ( $48.05 \%)$, for managing employees $(34.42 \%)$, and for managing logistical permits $(15.58 \%)$. Nevertheless, $15.58 \%$ would not use seasonal forecasts, and $4.55 \%$ gave other answers, such as being unsure whether they would use such forecasts because they do not expect that they would be useful to them.

As stated in the methods section, an aim of the present study is to discover whether surfing businesses' incomes depend on wave availability (Figure 6). The results show that $56.34 \%$ of participants believe that the income of the company/department varies depending on the availability of waves. They identified two factors that can cause a decrease in income: (1) periods with no waves and (2) periods with very large waves. However, $35.92 \%$ stated that income does not vary. The remaining $7.75 \%$ gave other answers, which included the following: (1) tourists come to surf when they have holidays, regardless of the wave quality; (2) income varies according to good or bad weather instead of according to wave quality; (3) stand up paddle (SUP) schools do not require waves; and (4) there is always some activity that tourists can practice or train for in the water.

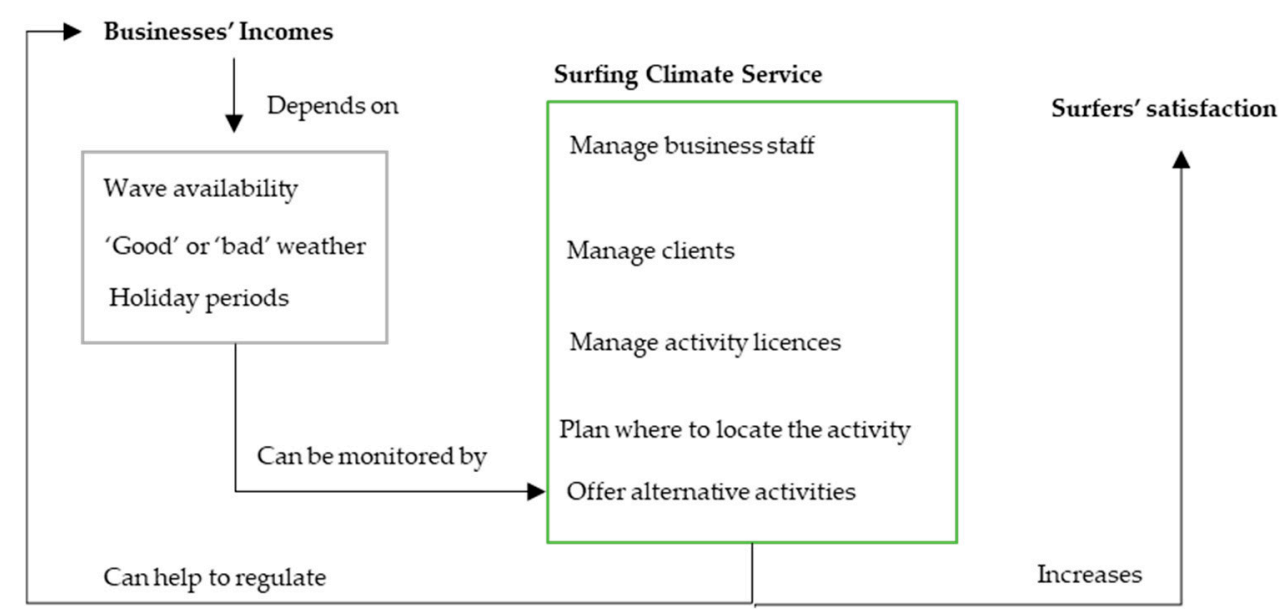

Figure 6. How SCS can help to regulate business income, according to surf schools.

In regard to those who do not believe that income varies depending on wave availability, their opinion is usually related to the fact that some companies are associated with glamping resorts and that clients will also go surfing when they are on holiday. Some stated that during the summer when the waves are not good for surfing, they actually have increased income.

Currently, $61.11 \%$ of surfing companies on the Iberian Peninsula offer other water activities besides surfing, and the remaining $38.89 \%$ offer only surfing as the company's unique activity. However, $43.42 \%$ would diversify their offerings of water activities if they had adequate information to assist good decision-making, and $25 \%$ would probably offer other water activities. The remaining $31.58 \%$ would not diversify their offerings. Referring to willingness to pay, $60.13 \%$ would not be willing to pay to receive seasonal forecasts; $32.28 \%$ might be willing to pay; and the remaining $7.59 \%$ would be willing to pay.

To conclude, we can extract the following statements about the usability of seasonal forecasting for surfing companies: (1) Companies see the potential of seasonal surfing forecasts for managing clients, employees, the location for their activity and for managing licenses and permits. (2) Companies identify the relationship between wave availability and income. Nevertheless, other factors also influence income, and these include: (F1) tourists' holidays and (F2) good or bad weather. (3) Over half of companies, $61.11 \%$, offer water activities besides surfing, but they would like to receive customized information to assist in decision making. Related to this, companies would be able to manage and plan other water activities when surfing is not possible. (4) The main channels desired for receiving information are apps for smartphones and websites. 


\subsection{Environmental Problems That Harm the Surfing Experience}

In previous sections, we have identified the types of meteorological and climatological information surfers require for a better surfing experience. However, environmental problems are also a factor that affects the quality of the surfing experience. In this sense, surfers identify general environmental problems in surf spots (Figure 7), then they reveal several actual examples of these problems in their usual surf spots.
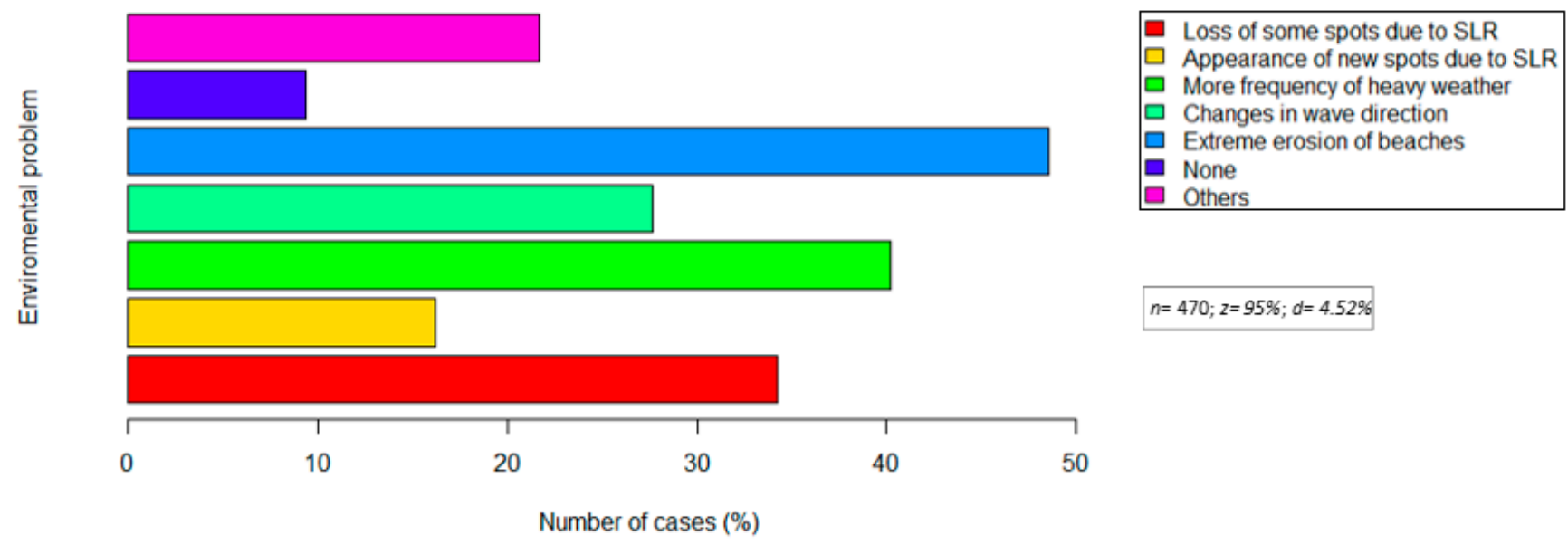

$n=470 ; z=95 \% ; d=4.52 \%$

Figure 7. Theoretical environmental problem perception from surfers' points of view.

Respondents could choose from among five different environmental impacts and could identify and describe other nonenvironmental impacts affecting surfing (multiple choice option). Referring to general environmental problems, the results show that extreme erosion of beaches $(48.51 \%)$, greater frequency of extreme weather events $(40.21 \%)$, and loss of some spots due to sea level rise (34.26\%) are the main environmental impacts that affect surfing from surfers' perspectives. Some (27.66\%) stated that changes in wave direction are an environmental impact that affects surfing, and $21.70 \%$ mentioned other kinds of environmental impacts. The appearance of new spots due to sea level rise is the least of the environmental problems identified $(16.17 \%)$, and $9.36 \%$ reported no environmental impacts that affect their surfing.

The answers focusing on detecting other theoretical environmental problems can be summarized as follows: (1) building harbors, dikes; (2) contamination; (3) massification; (4) loss of flora and fauna; (5) changes in climatology (ocean currents, sea temperature); (6) tourism; (7) and modifications of the sea floor and/or dune system.

Surfers identified multiple environmental changes to their usual surf spots (Table 5); the majority of these are interconnected. Using the problem-tree process, a conceptual model used as a diagnostic tool to analyze a sequence of events that eventually leads to a problem [47], it is possible to identify the major facts/problems and their corresponding causes and consequences. The main problems or factors in their usual surf spots highlighted by surfers are as follows: (1) pollution; (2) overtourism; (3) beach erosion, sea level rise, and dune system erosion; (4) changes in surfing availability; and (5) the presence of fewer tourists. The presence of people in surf spots is reflected in their impacts on human and natural systems. (1) Pollution in surf spots is fed by discharges from outfalls, inefficient pollution systems, increased population in the tourism season in tourist areas, and chemical pollution from factories. All these causes can be translated into human health problems as well as negative impacts on biodiversity. For example, some specific pollution problems are detected in Carcavelos for the presence of plastics and microplastics; and polyurethane balls in La Pineda. (2) Overtourism is also an identified problem in some surf-destination regions; this happens when a world surfing reserve is created to promote surfing-like in Ericeira-but no environmental protection plan is executed. This situation produces changes in water security as more people tend to increase pollution. In addition, sun and 
beach tourism development sometimes involves the construction of artificial beaches that modify genuine surf spots. (3) Beach erosion, sea level rise, and dune system erosion are three major threats for surfing activities; these may result in changes in wave breaks' characteristics and sea floor characteristics, and can result in the loss or appearance of surf spots. All these changes are results of the construction of breakwaters and dikes, massive construction on the coast, little sedimentary contribution, seasonal variability, and sand drainage or other massive movements of sand. In this line, some examples of sea level-rise impacts are detected in Salinas and Badalona. (4) Surfers also identified several changes in surfing-wave availability, due mainly to changes in primary swell direction and wind direction, and these facts can be translated into changes in the number of expected surfing days. (5) Some surfers identified that, at the present time, there are fewer surfing tourists due to the COVID-19 pandemic and its related travel and mobility restrictions. Thus, there has been a reduction in business income related to this group of tourists. Nevertheless, this situation is seen as an opportunity to gain greater water security, offer surfing activities to local surfers or inhabitants, and, as a result, increase the well-being of the population.

Table 5. Environmental problems observed in usual surf spots from surfers' perspectives.

\begin{tabular}{|c|c|c|c|c|c|}
\hline 㫐空 & Pollution & $\begin{array}{l}\text { Overtourism } \\
\text { Too many Tourists } \\
\text { in the Water }\end{array}$ & $\begin{array}{l}\text { Beach Erosion, Sea } \\
\text { Level Rise, and Dune } \\
\text { System Erosion }\end{array}$ & $\begin{array}{l}\text { Changes in } \\
\text { Surfing-Wave } \\
\text { Availability }\end{array}$ & Fewer Tourists \\
\hline 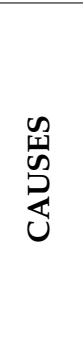 & $\begin{array}{c}\text { Discharges from } \\
\text { outfalls } \\
\text { Inefficient } \\
\text { management of } \\
\text { pollution systems } \\
\text { Increase in population } \\
\text { in tourism season } \\
\text { Chemical pollution } \\
\text { from factories }\end{array}$ & $\begin{array}{l}\text { Increase in tourism } \\
\text { flows before } \\
\text { COVID-19 pandemic } \\
\text { Promotion of surf } \\
\text { destination with no } \\
\text { environmental } \\
\text { protection plan }\end{array}$ & $\begin{array}{c}\text { Construction of } \\
\text { breakwaters and dikes } \\
\text { Massive construction on } \\
\text { the coast } \\
\text { Little sedimentary } \\
\text { contribution } \\
\text { Seasonal variability } \\
\text { Sand drainage/massive } \\
\text { sand movements }\end{array}$ & $\begin{array}{c}\text { Changes in } \\
\text { primary swell } \\
\text { direction. } \\
\text { Changes in wind } \\
\text { patterns }\end{array}$ & $\begin{array}{l}\text { COVID-19 pandemic: } \\
\text { restricted mobility }\end{array}$ \\
\hline 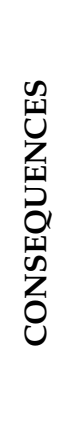 & $\begin{array}{c}\text { Human health } \\
\text { problems (gastritis, } \\
\text { otitis) } \\
\text { Affects the biodiversity } \\
\text { of surf spots }\end{array}$ & $\begin{array}{l}\text { Changes in security } \\
\text { in the water } \\
\text { Increase in pollution } \\
\text { Construction of } \\
\text { artificial beaches for } \\
\text { sun and beach } \\
\text { tourism }\end{array}$ & $\begin{array}{l}\text { Changes in wave breaks' } \\
\text { characteristics such as } \\
\text { shape and height } \\
\text { Sand beaches with } \\
\text { increasing presence of } \\
\text { rocks in relation to sand } \\
\text { Loss or appearance of } \\
\text { surf spots } \\
\text { Changes on sea floor }\end{array}$ & $\begin{array}{l}\text { Changes in the } \\
\text { number of } \\
\text { expected surfing } \\
\text { days. }\end{array}$ & $\begin{array}{l}\text { More security in the } \\
\text { water } \\
\text { Reduce local income } \\
\text { from tourists } \\
\text { New opportunities to } \\
\text { offer surfing activities } \\
\text { to local surfers } \\
\text { Increase well-being of } \\
\text { the population } \\
\text { Boost the local } \\
\text { economy }\end{array}$ \\
\hline
\end{tabular}

\subsection{Usual Surf Spots and Surf Tourism on the Iberian Peninsula}

A total of $40.90 \%$ of survey respondents affirmed that the place they chose to live was selected because of the availability of surfing. This confirms that surf spots are popular not only with tourists who surf but also local surfers. Figure 8 shows the location of usual surf spots (left) versus surf spots related to travel destinations (right). 


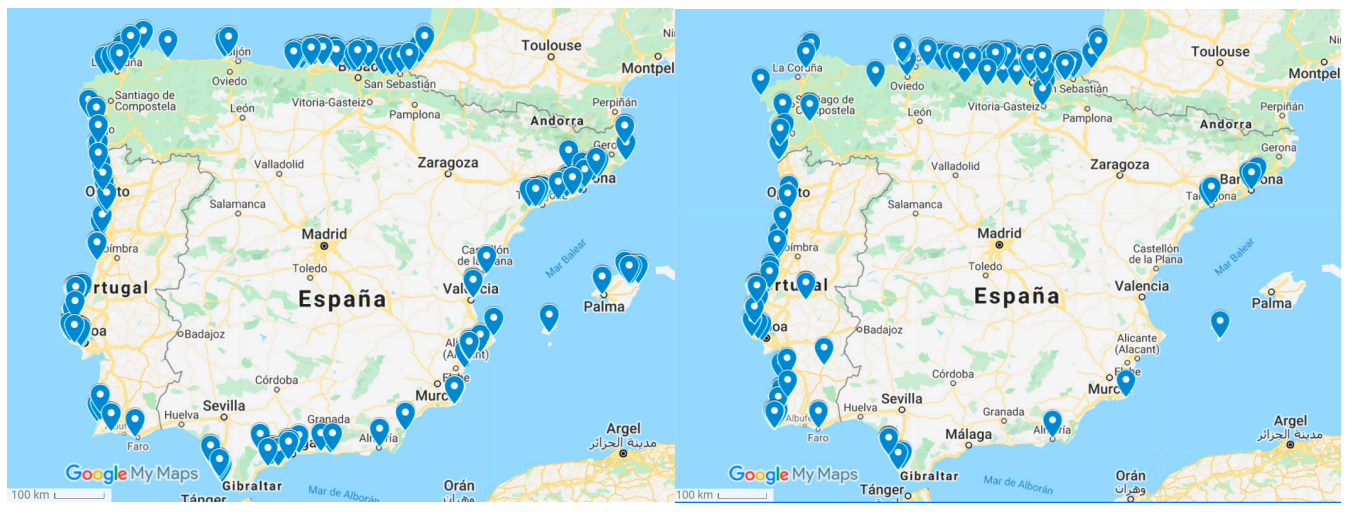

Figure 8. Usual surf spots (left) versus travel surf spots (right) located on the Iberian Peninsula.

We understand travel surf spots as places where surfers need to spend a minimum of one night away from their usual place of residence, whereas local surf spots work the other way. In relation to this, we can see that usual surf spots are distributed more homogeneously all around the Iberian Peninsula compared to travel surf spots. In relation to surf tourism, we can detect areas that are losers and others that are winners. The winners are located around the northern and western shores. The losing areas are those located around the eastern and southwestern shores.

Surfers stated that the information most frequently used when deciding where to surf is wave availability. As Boqué et al. [34] have noted, the western and northern shores are the locations that offer more expected surfing days per year; then, this information is translated into which areas surfers visit most frequently for the purpose of surf tourism.

\subsection{Design of SCS Prototype}

According to the results of the survey, surfers requested one channel where they could access all the various pieces of information that they consult when making decisions about where to surf. This survey, therefore, has identified a market opportunity for an app-packaged climate service for surfers.

Figure 9 represents a mock-up layout of an SCS prototype identifying the climate service marketplace [48]. Based on our results, this app, which, for convenience, we will call Surf Better, should contain the following items: first, end-users have to register (users will be asked to provide demographic information such as age, surfing skills, usual surf spots, and whether they are employed by a surf school). After registering, users can search specific surf spots and check for different items such as (1) forecasts, (2) real-time nowcasts, (3) users' shared surfing experiences, (4) surf tourism, and (5) local information. In this regard, specific items based on the forecast section include all the parameters mentioned in the previous section; in addition, forecasts will present the percentage of success and a comparison between the different models of prediction.

The real-time section includes all information related to nowcasts, including webcams and access to buoy data. Users can also post videos and/or photographs of their surf spots by indicating time and location.

The section for sharing surfing experiences will work as a registry of surfing sessions. Users should indicate day, time, surf-quality rating, pollution level, crowd level, and any environmental problems they observe. All this information will remain registered and will then be used as (a) a validation source for surfing forecasts and surf-wave climatology and (b) a registry of environmental problem perception. 


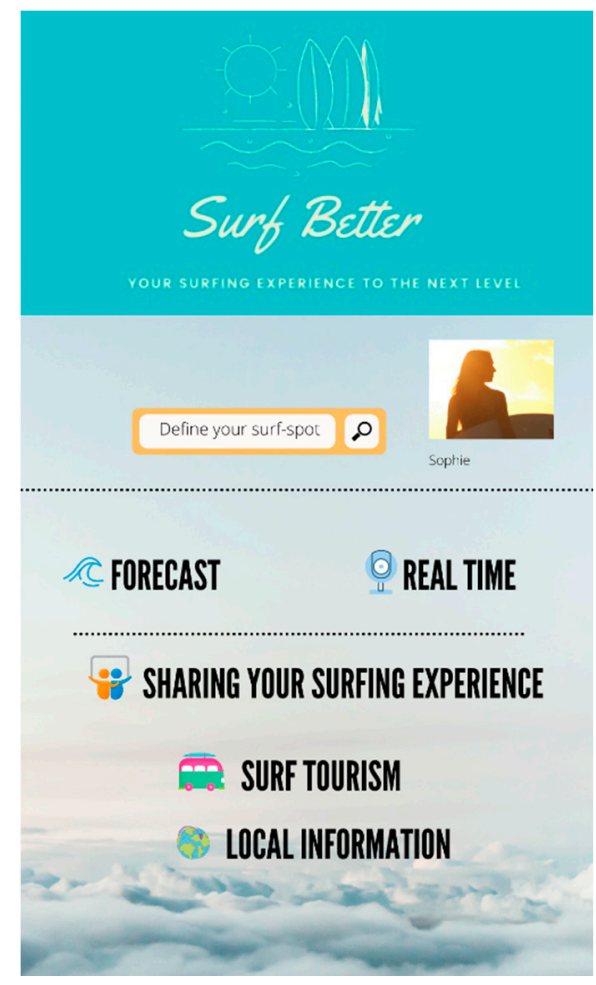

Figure 9. SCS app prototype.

When surfers are planning to travel for surfing, they can check the main source to assist their decision-making in regard to surf information about wave availability at the site $(67.02 \%)$ as well as information from friends and acquaintances (61.91\%). Cartography is also a source that helps surfers decide where to go on a surfing trip (38.72\%). Conversely, the least-checked information is that provided by tourist offices/tourist brands (7.45\%). The surf-tourism section includes seasonal forecasts, and explanations for them will be present with recommendations for surf schools in order to manage employees and clients in terms of where to establish their business, and for surfers to decide where they should go for surf tourism. This section will also include water tourism offers as information for surfers.

In the end, the local information section provides the surfer with information about the specific conditions needed for surfing that vary from surf spot to surf spot; these can include swell direction, wind direction, bottom type, surfbreak type, recommended level of surfing, and the best season for surfing at a particular location. This section can be enhanced by information contributed by app users.

\section{Discussion and Conclusions}

The purpose of this paper was to determine the main characteristics required for inclusion in the development of a new prototype for an SCS tailored for surfing practitioners and companies who offer surfing services.

The present research represents an advance in the knowledge about the requirements needed for developing weather services targeted at surfing activities. This information was obtained from the data extracted from the online survey. Following Buckley [49] and Ponting [50], we identify surf tourism as occurring when surfers travel to enjoy this activity and spend at least one night away from their usual place of residence. In addition, we consider information from surfers who do not spend one night or more away from their place of residence. This is because, as Reineman et al. [51,52] presented, local surfers' knowledge is relevant to understanding each surf-spot's mechanism. The results of the survey allow us to validate the knowledge of local surfers and its value. In this sense, the results show that one of the requirements for a new SCS is to include location-specific 
information contributed by local experienced surfers. This information can include-but is not limited to- the type of tide that works better in the surf spot, the localization of surfbreaks and main currents, the level of surfing at different surfbreaks, and the best season of the year to surf at that location.

As shown in the results section, the analysis reveals that $84.47 \%$ of surfers always consult sea-state information, $15.53 \%$ sometimes do, and $0 \%$ never do. This demonstrates that sea-state information is a key element for planning, developing, and managing surfing activities. This reality confirms the need for surfers to seek the right combination of swell size, swell direction, wind strength, wind direction, tide, sand, and rock, as surfers are always hunting the ephemeral wave [53].

In order to improve SCS, several factors that can provide new opportunities to develop more-advanced SCS must be considered. These should be focused on: (1) developing greater accuracy and precision and locally developed forecasts; (2) designing a customizable format that is easy to read and interpret for all levels of surfing; and (3) adding information that is based on the knowledge of local surfers and surfing experts, as well as information about pollution and atmospheric maps and cartography.

The present research provides information about the need to assist different surfing user-communities, specifically surfers and companies that offer surfing activities. It has also been shown that, when surfers decide to travel for surfing purposes, the information used most often is that related to wave availability. The information used least often is that provided by tourist offices/tourist brands. Regarding this certainty, further research should focus on exploring whether this limitation is due to a lack of available information from these organizations or due to poor communication between tourism boards and surfers. In regard to this, we encourage the alliance of tourism boards, surf schools, tourist-accommodation establishments, and surfers-both local and those who travel to go surfing - in order to empower and better manage surfing destinations.

In a global tourism context, it is important to mention that some surfing appslike Magicseaweed - used in the Iberian Peninsula are also consulted abroad, such as in Australia and Hawaii. This is because they are designed for a global coverage. Even so, there are some more locally developed surfing apps, such as Medswells, which focuses its predictions only on a specific area of the Mediterranean coast.

Future research might focus on developing a seasonal forecast for surfing activity, as it has been shown that this kind of prediction does not currently exist. As stated by Todd Cool [54], as with any forecast, the further out the prediction, the lower the tolerance for accuracy. Nevertheless, a significant number of surfers reported that if they could access such information, it might be useful for planning their surfing trips. Surfing companies also report that they would take advantage of this kind of forecast; seasonal forecasting would be useful to them for managing their clients, employees, and licenses. It would also help them in their decision-making to know where to locate their business for the greatest amount of activity and whether they should consider offering complementary activities that do not require wave availability, for example, standup paddleboarding and kayaking. In this sense, a short-term forecast is useful for surfers and companies; even so, it requires some improvements. However, seasonal forecasts could play another role in managing surfing activity in the medium term.

As noted by Groves et al. [53], surfers are aware of the negative impact of human activity on marine environments. The present study affirms that surf spots present important environmental problems. In some cases, promoting surfing tourism can lead to exacerbating those problems or creating new ones. For this reason and in regard to our results, we propose adding to the SCS a register of observed environmental problems such as CoastSnap [55] based on citizen science and creating community surf-spot monitoring. In doing so, the service can present a historical data registry that looks at (1) surfing-session registry evaluation and (2) environmental problem detection, and then processes this information to manage the surf spot. The outcomes of this monitoring would contribute to implementing measures for protecting surf-spot environments and improving local 
forecasts based on machine learning. This structure will help to feed the validity and accuracy of the forecast and contribute to raise the credibility of it.

It is important to rethink the needs of surfers and surf companies. The requirements of the two groups are quite different, with individual surfers wanting to know if it is worth travelling to a location, and the companies being interested in expenditures and numbers likely to be present. These differences may be considered when developing SCS.

Surfing tourism research is in its early stages [56]. Research has explored advances in climate services in different sectors, including mainly the priority areas defined by the Global Framework for Climate Services: agriculture and food security; disaster risk reduction; and energy, health, and water. Some research focusing on CS has highlighted other sectors such as tourism, but research in the field of surfing tourism that analyzes SCS has not been conducted before now.

To conclude, we can affirm that our results clearly define the first steps in how an SCS should be developed in the framework of surf spots on the Iberian Peninsula. When an effective SCS has been developed, it will have clear implications for the management of these tourism areas and will provide insights into whether surfing activities in these areas may be successful. The survey model used for the research presented in this article can be found online [57]: see Appendix A.

Author Contributions: Conceptualization, A.B.C. and E.A.; Data curation, A.B.C. and E.A.; Formal analysis, A.B.C. and E.A.; Funding acquisition, A.B.C. and E.A.; Investigation, A.B.C. and E.A.; Methodology, A.B.C. and E.A.; Project administration, A.B.C. and E. A.; Resources, A.B.C. and E.A.; Software, A.B.C. and E.A.; Supervision, A.B.C. and E.A.; Validation, A.B.C. and E.A.; Visualization, A.B.C. and E. A.; Writing-original draft, A.B.C. and E.A.; Writing-review \& editing, A.B.C. and E.A. All authors have read and agreed to the published version of the manuscript.

Funding: Research within INDECIS project (INDECIS is part of ERA4CS, an ERA-NET initiated by JPI Climate and funded by FORMAS (SE), DLR (DE), BMWFW (AT), IFD (DK), MINECO (ES), ANR (FR) with cofunding by the European Union Grant 690462). This article publication has been possible with the support of the Secretaria d'Universitats i Recerca del Departament d'Empresa i Coneixement de la Generalitat de Catalunya, the European Union (UE) and the European Social Fund (ESF) (Doctoral Research Grant 2020FI_B00493-Formació personal investigador novell).

Institutional Review Board Statement: Not applicable.

Informed Consent Statement: Not applicable.

Data Availability Statement: Not applicable.

Acknowledgments: We thank all participants of the survey for their insights' contributions.

Conflicts of Interest: The authors declare that they have no known competing financial interests or personal relationships that could have appeared to influence the work reported in this paper.

\section{Appendix A. Survey Model}

Survey model available online: https:/ / forms.gle/yQrTeUARKaTaZy7z7.

\section{Appendix B. Summary of Survey Responses}

Table A1. Summary of Survey Responses.

\begin{tabular}{llcc}
\hline \multirow{2}{*}{ 0. Have you ever surfer on the Iberian Peninsula? } & \multicolumn{2}{c}{ Yes } & No \\
\cline { 2 - 3 } & $97.77 \%$ & $2.23 \%$ \\
\hline \multirow{2}{*}{ 1. Gender } & $\%$ Male & $\%$ Female \\
\hline
\end{tabular}


Table A1. Cont.

\begin{tabular}{|c|c|c|c|c|c|}
\hline \multirow{2}{*}{ 2. Age } & {$[16-25)$} & {$[25-35)$} & {$[35-45)$} & {$[45-55)$} & $>=55$ \\
\hline & $26.00 \%$ & $38.90 \%$ & $24.95 \%$ & $8.46 \%$ & $1.69 \%$ \\
\hline \multirow{2}{*}{ 3. Nationality } & Spanish & Portuguese & Others & & \\
\hline & $66.52 \%$ & $17.29 \%$ & $16.19 \%$ & & \\
\hline 4. Municipality of residence & \multicolumn{5}{|c|}{ See Figure A1 } \\
\hline \multirow{2}{*}{ 5. Was the place you live chosen to be able to surf? } & Yes & No & NA & & \\
\hline & $40.90 \%$ & $59.10 \%$ & $0.64 \%$ & & \\
\hline \multirow{2}{*}{ 6. Years of surfing } & $<5$ & {$[5-10)$} & {$[10,15)$} & {$[15,20)$} & $>=20$ \\
\hline & $20.85 \%$ & $27.66 \%$ & $14.47 \%$ & $12.13 \%$ & $24.89 \%$ \\
\hline \multirow[t]{2}{*}{ 7. Board water sport practiced more frequently } & Bodyboard & Shortboard & Longboard & $\begin{array}{l}\text { Stand up } \\
\text { Paddle }\end{array}$ & \\
\hline & $11.49 \%$ & $64.68 \%$ & $17.66 \%$ & $6.17 \%$ & \\
\hline \multirow{2}{*}{ 8. Level of surfing } & Beginner & Intermediate & Advanced & & \\
\hline & $5.74 \%$ & $25.11 \%$ & $69.15 \%$ & & \\
\hline \multirow{2}{*}{$\begin{array}{l}\text { 9. Do you dedicate yourself or have you dedicated yourself } \\
\text { professionally to surfing (competition, instructor, judge ... )? }\end{array}$} & Yes & No & & & \\
\hline & $39.15 \%$ & $60.85 \%$ & & & \\
\hline
\end{tabular}

10. Indicate your usual spots

Section 3.4

See Figure A2

11. What do you think are the environmental impacts that affect surfing? (multiple choice)

Section 3.3

12. Please list any changes you have observed in your usual spot (s) that harm or benefit the practice of the sport. Indicate in which surf spot

Section 3.3

13. Do you have to travel at a distance that involves you spending a night away from home in order to surf surf?

\begin{tabular}{cc} 
Yes & No \\
\hline $88.30 \%$ & $11.70 \%$
\end{tabular}

14. Indicate some of you travel spots that you would like to highlight (if possible, within the Iberian Peninsula)

15. When do you travel (spend a minimum of 1 night away from home) do you consult the state of the sea in a different way? (multiple choice)

Section 3.4

See Figure A3

Section 3.1

\begin{tabular}{llc} 
16. Where do you surf most often? & Home & Not home \\
\cline { 2 - 3 } & $88.30 \%$ & $11.70 \%$
\end{tabular}

17. Indicate what information you consult before going surfing and assess its quality $(1=$ very bad $-5=$ very good) [Friends / family inform me]

18. Before going surfing, do you consult information to know the state of the sea?

Section 3.1

19. How far long in advance do you check the forecast? (multiple choice)

20. What website or application do you consult to look at the prediction?

Section 3.1

21. What parameters do you look at when checking at the wave forecasts?

Section 3.1

Section 3.1

Section 3.1

22. Do you know what the significant height of the wave is? Yes No

$71.91 \% \quad 13.19 \%$

I have heard about it, but I don't know what it is $14.89 \%$

Section 3.2

23. What do you think could be improved from the surf forecasts?

Section 3.2 you had the information of the summer

25. In what format would you like to receive seasonal forecast information? (multiple choice)

Section 3.2

26. Filter question

27. If you had seasonal information, would it be useful to you? (multiple choice)

Section 3.2 
Table A1. Cont.

\begin{tabular}{lll}
\hline 28. & In what format would you like to receive the information? & Section 3.2 \\
\hline 29. & Does the income of the company/department vary depending on the availability of waves? & Section 3.2 \\
\hline 30. & Does your company currently offer other water activities apart from surfing? & Section 3.2 \\
\hline 31. & Would you be willing to pay to receive seasonal information? & Section 3.2 \\
\hline 32. Do you think you would diversify the offer of aquatic activities if you had adequate information on & Section 3.2 \\
the state of the sea? & Add comments that you think you can contribute extra information to the study: \\
\hline 33. & If you want to stay informed of the results of the investigation you can write your email here \\
\hline
\end{tabular}

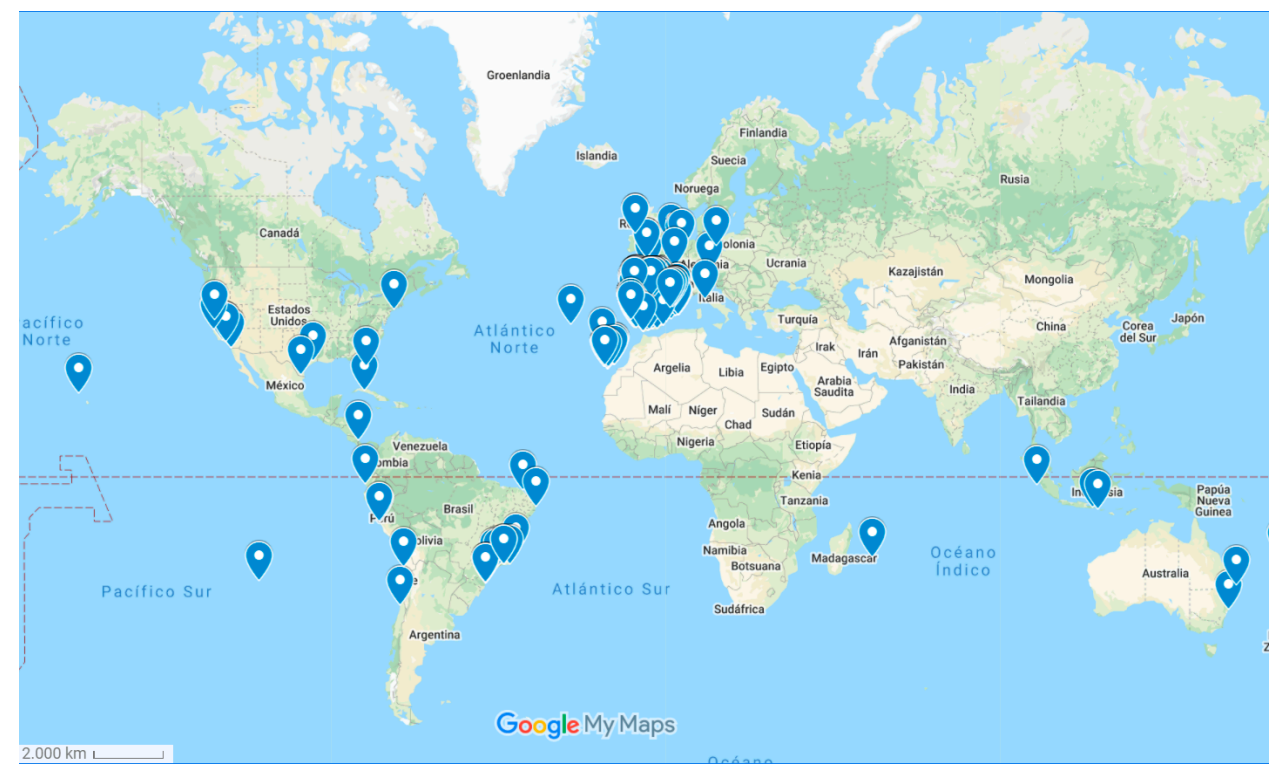

Figure A1. Place of residence.

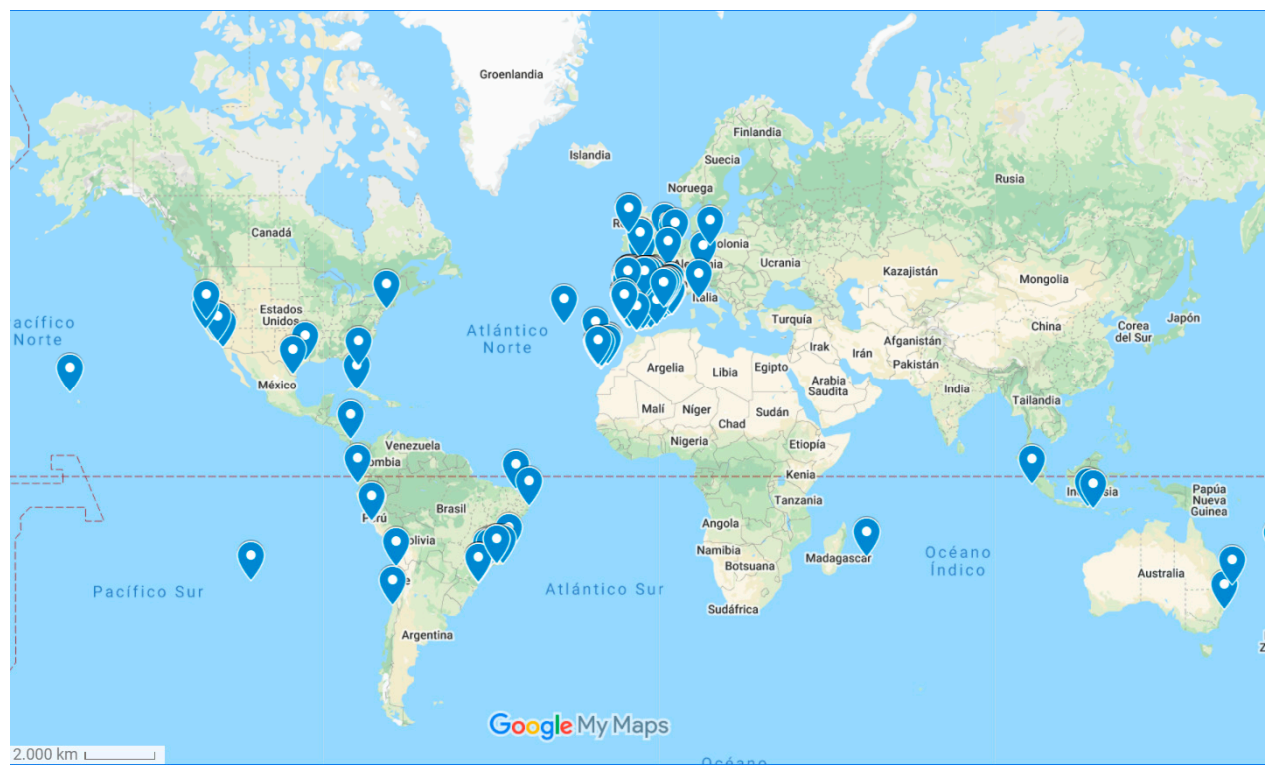

Figure A2. Usual surf spots. 


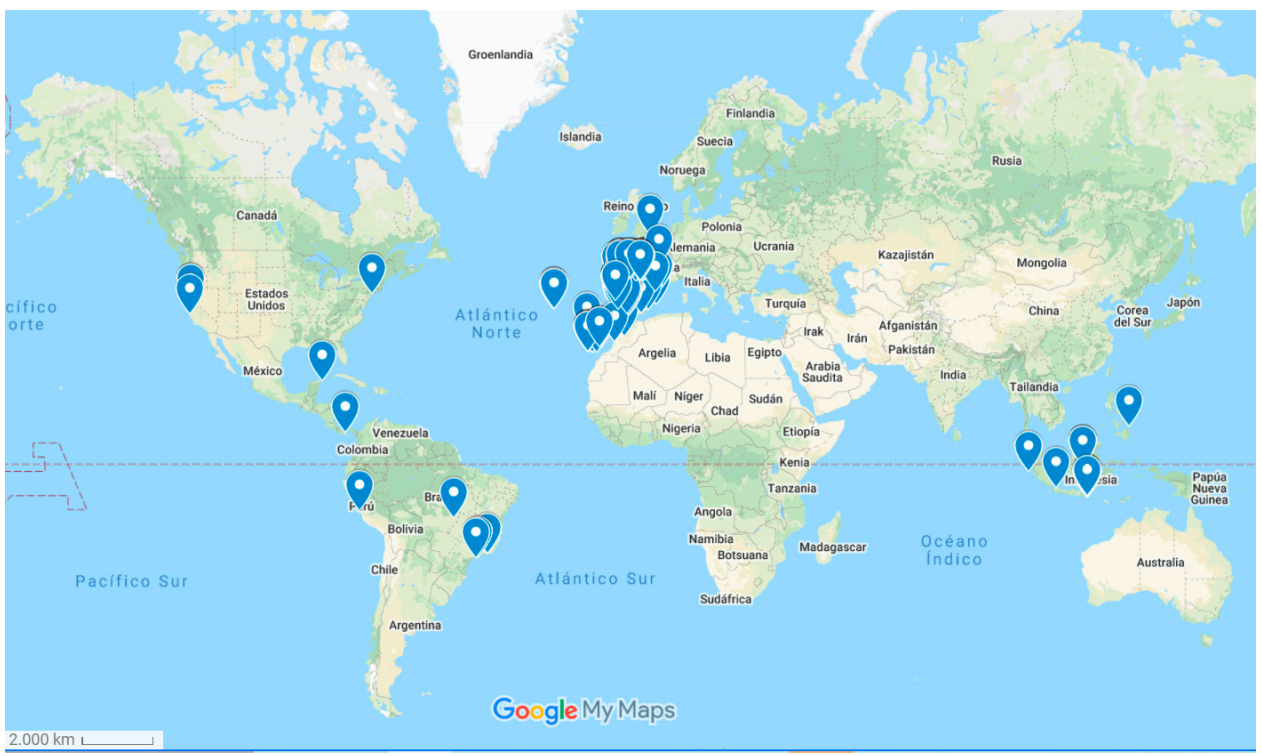

Figure A3. Travel surf spots.

\section{References}

1. Damm, A.; Köberl, J.; Stegmaier, P.; Alonso, E.J.; Harjanne, A. The market for climate services in the tourism sector-An analysis of Austrian stakeholders' perceptions. Clim. Serv. 2020, 17, 100094. [CrossRef]

2. Hewitt, C.; Mason, S.J.; Walland, D. The Global Framework for Climate Services. Nat. Clim. Chang. 2012, 2, 831-832. [CrossRef]

3. Jancloes, M.; Thomson, M.; Costa, M.M.; Hewitt, C.; Corvalan, C.; Dinku, T.; Lowe, R.; Hayden, M. Climate Services to Improve Public Health. Int. J. Environ. Res. Public Health 2014, 11, 4555-4559. [CrossRef] [PubMed]

4. Connor, S.J.; Omumbo, J.; Green, C.; DaSilva, J.; Mantilla, G.; Delacollette, C.; Thomson, M. Health and cli-mate-needs. Procedia Environ. Sci. 2010, 1, 27-36. [CrossRef]

5. Williges, K.; Mechler, R.; Bowyer, P.; Balkovic, J. Towards an assessment of adaptive capacity of the European agricultural sector to droughts. Clim. Serv. 2017, 7, 47-63. [CrossRef]

6. Coulibaly, J.Y.; Birachi, E.A.; Kagabo, D.M.; Mutua, M. Climate Services for Agriculture in Rwanda Baseline Survey Report; CCAFS: Wageneigen, The Netherlands, 2017.

7. Vaughan, C.; Hansen, J.; Roudier, P.; Watkiss, P.; Carr, E. Evaluating agricultural weather and climate services in Africa: Evidence, methods, and a learning agenda. Wiley Interdiscip. Rev. Clim. Chang. 2019, 10, 586. [CrossRef]

8. Rosas, G.; Gubler, S.; Oria, C.; Acuña, D.; Avalos, G.; Begert, M.; Castillo, E.; Croci-Maspoli, M.; Cubas, F.; DaPozzo, M.; et al. Towards implementing climate services in Peru-The project CLIMANDES. Clim. Serv. 2016, 4, 30-41. [CrossRef]

9. Dayamba, D.S.; Ky-Dembele, C.; Bayala, J.; Dorward, P.; Clarkson, G.; Sanogo, D.; Mamadou, L.D.; Traoré, I.; Diakité, A.; Nenkam, A.; et al. Assessment of the use of Participatory Integrated Climate Services for Agriculture (PICSA) approach by farmers to manage climate risk in Mali and Senegal. Clim. Serv. 2018, 12, 27-35. [CrossRef]

10. Lowe, R.; Bailey, T.C.; Stephenson, D.B.; Jupp, T.E.; Graham, R.J.; Barcellos, C.; Carvalho, M.S. The development of an early warning system for climate-sensitive disease risk with a focus on dengue epidemics in Southeast Brazil. Stat. Med. 2013, 32, 864-883. [CrossRef]

11. Dinku, T.; Asefa, K.; Hilemariam, K.; Grimes, D.; Connor, S. Improving availability, access and use of climate information. WMO Bull. 2011, 60. Available online: http://www.wmo.int/pages/publications/bulletin_en/archive/60_2_en/60_2_Tufa_en.html (accessed on 20 February 2021).

12. Soares, M.B.; Alexander, M.; Dessai, S. Sectoral use of climate information in Europe: A synoptic overview. Clim. Serv. 2018, 9 , 5-20. [CrossRef]

13. Martín, M.B.G. Weather, climate and tourism a geographical perspective. Ann. Tour. Res. 2005, 32, 571-591. [CrossRef]

14. Smith, K. The influence of weather and climate on recreation and tourism. Weather 1993, 48, 398-404. [CrossRef]

15. Aguilar, E.; Reverté, F.G. El valor de los factores geográficos en la localización de instalaciones turísti-co-recreativas. El caso de Port Aventura. Vila-Seca y Salou (Tarragona). In Cambios Regionales a Finales del Siglo XX: XIV Congreso Nacional de Geografía: Comunicaciones; Asociación Española de Geografía: Madrid, Spain, 1995; pp. 279-282.

16. Barbier, B. Les stations de sports d'hiver françaises et le milieu physique. Geogr. Pol. 1984, 49, $109-116$.

17. Becker, S. Bioclimatological rating of cities and resorts in South Africa according to the Climate Index. Int. J. Clim. 2000, 20, 1403-1414. [CrossRef]

18. Besancenot, J.P. Premières données sur les stress bioclimatiques moyens en France. In Annales de geographie; Armand Colin: Paris, France, 1974; pp. 497-530. 
19. Mieczkowski, Z. The tourism climatic index: A method of evaluating world climates for tourism. Can. Geogr./Géographe Can. 1985, 29, 220-233. [CrossRef]

20. Scott, D.; Rutty, M.; Amelung, B.; Tang, M. An Inter-Comparison of the Holiday Climate Index (HCI) and the Tourism Climate Index (TCI) in Europe. Atmosphere 2016, 7, 80. [CrossRef]

21. Becker, S. Beach comfort index-A new approach to evaluate the thermal conditions of beach holiday resorts us-ing a South African example. GeoJournal 1998, 44, 297-307. [CrossRef]

22. Scott, D.; Lemieux, C.; Malone, L. Climate services to support sustainable tourism and adaptation to climate change. Clim. Res. 2011, 47, 111-122. [CrossRef]

23. Lise, W.; Tol, R.S. Impact of climate on tourist demand. Clim. Chang. 2002, 55, 429-449. [CrossRef]

24. Moreno, A.; Amelung, B. Climate change and tourist comfort on Europe's beaches in summer: A reassessment. Coast. Manag. 2009, 37, 550-568. [CrossRef]

25. Grillakis, M.G.; Koutroulis, A.G.; Seiradakis, K.D.; Tsanis, I.K. Implications of 2 C global warming in Euro-pean summer tourism. Clim. Serv. 2016, 1, 30-38. [CrossRef]

26. Gable, F.J. Climate change impacts on Caribbean coastal areas and tourism. J. Coast. Res. 1997, 49-69.

27. Le Cozannet, G.; Nicholls, R.J.; Hinkel, J.; Sweet, W.V.; McInnes, K.L.; Van De Wal, R.S.W.; Slangen, A.B.A.; Lowe, J.A.; White, K.D. Sea Level Change and Coastal Climate Services: The Way Forward. J. Mar. Sci. Eng. 2017, 5, 49. [CrossRef]

28. Scott, D.; Wall, G.; McBoyle, G. Chapter 3. The Evolution of the Climate Change Issue in the Tourism Sector. Tour. Recreat. Climate Chang. 2005, 22, 44-60. [CrossRef]

29. Buckley, R. Perceived Resource Quality as a Framework to Analyze Impacts of Climate Change on Adventure Tourism: Snow, Surf, Wind, and Whitewater. Tour. Rev. Int. 2017, 21, 241-254. [CrossRef]

30. Ponting, J. Projecting Paradise: The Surf Media and the Hermeneutic Circle in Surfing Tourism. Tour. Anal. 2009, 14, 175-185. [CrossRef]

31. Fluker, M. Riding the wave: Defining surf tourism, the Council of Australian University Tourism and Hospitality Educators Conference. Coffs Harbour, Australia; Available online: https:/ / ro.uow.edu.au/commpapers/248/ (accessed on 20 February 2021).

32. Martin, S.A.; Assenov, I. Developing a Surf Resource Sustainability Index as a Global Model for Surf Beach Conservation and Tourism Research. Asia Pac. J. Tour. Res. 2013, 19, 760-792. [CrossRef]

33. Espejo, A.; Losada, I.J.; Méndez, F.J. Surfing wave climate variability. Glob. Planet. Chang. 2014, 121, 19-25. [CrossRef]

34. Peñas de Haro, P. La geografía del surf y el bodyboard en Mallorca, clima y turismo activo. Ph.D. Thesis, Universitat de les Illes Balears, Baleares, Spain, February 2019.

35. Ciurana, A.B.; Aguilar, E. Expected Distribution of Surfing Days in the Iberian Peninsula. J. Mar. Sci. Eng. 2020, 8, 599. [CrossRef]

36. Dolnicar, S.; Fluker, M. Behavioural market segments among surf tourists: Investigating past destination choice. J. Sport Tour. 2003, 8, 186-196. [CrossRef]

37. Mach, L.; Ponting, J.; Brown, J.; Savage, J. Riding waves of intra-seasonal demand in surf tourism: Analysing the nexus of seasonality and 21st century surf forecasting technology. Ann. Leis. Res. 2020, 23, 184-202. [CrossRef]

38. Towner, N. Searching for the perfect wave: Profiling surf tourists who visit the Mentawai Islands. J. Hosp. Tour. Manag. 2016, 26, 63-71. [CrossRef]

39. Reiblich, J. Greening the tube: Paddling toward comprehensive surf break protection. Env.: Envtl. L. Pol'y J. 2013, $37,45$.

40. Scheske, C.; Arroyo Rodriguez, M.; Buttazzoni, J.E.; Strong-Cvetich, N.; Gelcich, S.; Monteferri, B.; Ruiz, M. Surfing and marine conservation: Exploring surf-break protection as IUCN protected area categories and other effec-tive area-based conservation measures. Aquat. Conserv. Mar. Freshw. Ecosyst. 2019, 29, 195-211. [CrossRef]

41. Amorim, R.C.; Rocha, A.; Oliveira, M.; Ribeiro, C. Efficient delivery of forecasts to a nautical sports mo-bile Application with semantic data services. In C3S2E '16: Proceedings of the Ninth International C* Conference on Computer Science E Software Engineering; Association for Computing Machinery: New York, NY, USA, 2016; pp. 7-12.

42. Pontes Caselli, R.; Ferreira, M.G.G. Systematic proposal for UX centered mobile apps for tracking perfor-mance in sports through an application in recreational surfing. Prod. Manag. Dev. 2018, 16, 37-46. [CrossRef]

43. Scott, V. Who Will Surf for Science? Understanding Motivations to Engage Surfers in Citizen Science with Smart-fin. Ph.D. Thesis, University of California, Oakland, CA, USA, 2019.

44. Edwards, A.; Stephenson, W. Assessing the potential for surf break co-management: Evidence from New Zea-land. Coast. Manag. 2013, 41, 537-560. [CrossRef]

45. Esparza, D. De Hawai al Mediterráneo: La génesis del surf en España. (From Hawaii to the Mediterranean Sea: The Beginnings of Surfing in Spain). RICYDE. Rev. Int. Cienc. Deport. 2011, 7, 370-383. [CrossRef]

46. Álvarez Esteban, R. Las preguntas de respuesta abierta y cerrada en los cuestionarios. Análisis Estadístico Inf. Metodol. Encuestas 2003, 5, 45-54.

47. Fussel, W. Treating the cause, not the symptom. ILEA Newsl. 1995, 11, 30-31.

48. Mysiak, J.; Perrels, A.; Larosa, F.; Harjanne, A. Policy recommendations, promising resourcing and business models for climate services (deliverable 5.4-policybrief). Available online: http://eu-macs.eu/wp-content/uploads/2017/01/EUMACS_D54_ Policy_Brief_final.pdf (accessed on 20 February 2021).

49. Buckley, R. Surf Tourism and Sustainable Development in Indo-Pacific Islands. I. The Industry and the Islands. J. Sustain. Tour. 2002, 10, 405-424. [CrossRef] 
50. Ponting, J. Consuming Nirvana: An Exploration of Surfing Tourist Space. Ph.D. Thesis, Open Publications of UTS Scholars: Sydney, Australia 2008. Ph.D. Thesis, Open Publications of UTS Scholars, Sydney, Australia, 2008.

51. Reineman, D.R. The utility of surfers' wave knowledge for coastal management. Mar. Policy 2016, 67, 139-147. [CrossRef]

52. Reineman, D.R.; Thomas, L.N.; Caldwell, M.R. Using local knowledge to project sea level rise impacts on wave resources in California. Ocean Coast. Manag. 2017, 138, 181-191. [CrossRef]

53. Groves, A.; Klanten, R.; Funk, M.; Crockett, D. Surf Odyssey: The Culture of Wave Riding; Die Gestalten Verlag GmbH \& Co. KG.: Berlin, Germany, 2016.

54. Todd Cool, N. The WetSand WaveCast Guide to Surf Forecasting. A Simple Approach to Planning the Perfect Sessions; iUniverse, Inc.: Bloomington, Indiana, 2003.

55. User, S. Home-CoastSnap—Citizen Science App. [online] Coastsnap.com. 2021. Available online: https://www.coastsnap.com/ (accessed on 23 February 2021).

56. Valencia, L.; Osorio García, M.; Serrano Barquín, R.D.C. Turismo de surf: Revisión de nuevas líneas y temát-icas de investigación (2012-2018). Investig. Turísticas 2020, 20, 215-238.

57. Boqué, A.; Aguilar, E. Can You help Us to Predict Waves for Surfing? Available online: https://forms.gle/yQrTeUARKaTaZy7z7 (accessed on 20 February 2021). 